\title{
Valproic Acid Promotes Early Neural Differentiation in Adult Mesenchymal Stem Cells Through Protein Signalling Pathways
}

\author{
Jerran Santos ${ }^{1, *(\mathbb{D})}$, Thibaut Hubert ${ }^{1,2}$ and Bruce K Milthorpe ${ }^{1(\mathbb{C}}$ \\ 1 Advanced Tissue Regeneration \& Drug Delivery Group, School of Life Sciences, \\ University of Technology Sydney, P.O. Box 123, Broadway, NSW 2007, Australia; \\ tibo.hubert@gmail.com (T.H.); Bruce.Milthorpe@uts.edu.au (B.K.M.) \\ 2 Ecole Nationale Supérieure D'agronomie et des Industries Alimentaires (ENSAIA), Université de Lorraine, \\ 2 Avenue de la Forêt de Haye, 54505 Vandœuvre-lès-Nancy, France \\ * Correspondence: Jerran.Santos@uts.edu.au; Tel.: +61-(2)-9514-1353
}

Received: 23 January 2020; Accepted: 26 February 2020; Published: 4 March 2020

\begin{abstract}
Regenerative medicine is a rapidly expanding area in research and clinical applications. Therapies involving the use of small molecule chemicals aim to simplify the creation of specific drugs for clinical applications. Adult mesenchymal stem cells have recently shown the capacity to differentiate into several cell types applicable for regenerative medicine (specifically neural cells, using chemicals). Valproic acid was an ideal candidate due to its clinical stability. It has been implicated in the induction of neural differentiation; however, the mechanism and the downstream events were not known. In this study, we showed that using valproic acid on adult mesenchymal stem cells induced neural differentiation within $24 \mathrm{~h}$ by upregulating the expression of suppressor of cytokine signaling 5 (SOCS5) and Fibroblast growth factor 21 (FGF21), without increasing the potential death rate of the cells. Through this, the Janus Kinase/Signal Transducer and Activator of Transcription (JAK/STAT) pathway is downregulated, and the mitogen-activated protein kinase (MAPK) cascade is activated. The bioinformatics analyses revealed the expression of several neuro-specific proteins as well as a range of functional and structural proteins involved in the formation and development of the neural cells.
\end{abstract}

Keywords: adipose derived stem cells; valproic acid; protein interactions; MAPK pathway; JAK/STAT pathway

\section{Introduction}

Regenerative and translational medicine is a rapidly expanding area made possible by the availability of an abundant source of stem cells, particularly autologous adult mesenchymal stem cells acquired from lipoaspirates termed adipose derived stem cells (ADSCs). The application of autologous ADSCs to neural regeneration and repair therapies is of great interest due to the potential to reverse or limit the exacerbation of injuries that have severe effects on the quality of life while avoiding rejection [1].

Several studies have explored the effect of small molecule chemical inducers on the potential to drive neurogenic differentiation in stem cells. At optimized concentrations and short treatment times, chemicals such as beta-mercaptoethanol (BME) and dimethylsulfoxide (DMSO), have shown the potential to induce a structural and molecular phenotype in stem cells that resemble differentiating neural cells [2,3]. Not surprisingly, these molecules had negative effects inducing a range of stress and apoptotic markers with an increasing treatment time frame. Alternatively, less harsh chemicals with similar actions, such as butylated hydroxyanisole (BHA), retinoic acid (RA) and other chemical 
derivatives, have also shown a marked capacity for improving neural differentiation while decreasing cellular stress and death [4-7]. Valproic acid (VPA), as a focus molecule, has garnered some attention in neurogenic differentiation research, and was previously explored in certain stem cell types; however, the extent of the differentiation was not completely elucidated $[8,9]$.

Valproic acid (VPA) is a short-chain fatty acid that is well known as a histone deacetylase (HDAC) inhibitor [10]. It is an established drug in epilepsy therapy and can be used clinically as an anticonvulsant and a mood stabilizer [11]. Its proprieties on adult neuron cells are known and its actions on transcription have been previously studied at variable concentrations in vitro [12]. Studies have proven that VPA can affect the proliferation and the differentiation of neural crest progenitors and hippocampal neural stem cells [13]. Furthermore, VPA was shown to increase white matter repair and neurogenesis after a stroke by supporting the survival and new growth of oligodendrocytes, as well as myelination and axonal density [14]. The effect of VPA inducing differentiation in other stem cell types has been studied to a lesser extent.

VPA is minimally cytotoxic and biologically relevant. The induction by VPA of placental mesenchymal stem cells toward neuronal differentiation has been analysed using the criteria of altered cell morphology, reduced proliferation, and the expression of marker genes [13]. VPA treatment for up to ten days induced profound changes in cell morphology, which were characterized by less tightly packed cells within the colonies and the generation of long filamentous structures [8]. VPA has a definite effect on stem cells and induced morphological changes that progressed to a stage of preneuronal-like cell.

Further studies showed that VPA influences the proliferation and differentiation of neuronal cells by expressing a small set of specific markers [15]. However, little is known about the downstream events. The role of VPA in protein expression involved in the cell cycle and neuronal differentiation was also investigated. It was shown that treatment with VPA during the progenitor stages resulted in the strong inhibition of cell proliferation and the induction of neuronal differentiation, accompanied by increases in the expression of pro-neural transcription factors and in neuronal cell numbers [15]. Furthermore, it was previously demonstrated that VPA initiated catecholaminergic neuronal differentiation. VPA launches differentiation mechanisms in sympathoadrenal progenitor cells that result in increased generation of functional neurons [9]. However, the target of VPA on the neuronal differentiation pathways is also largely unknown. A research void exists in the molecular mechanisms that play a role in ADSCs differentiation toward neuronal phenotypes.

Previous studies on how VPA affects the neural differentiation are largely based on the impact of the VPA on the transcription through inhibition of the histone deacetylases (HDACs). This study focuses on the VPA effects on ADSCs as analysed by a proteomics approach, with the aim to compare the effects of the neural induction by VPA to controls and the effects of neurobasal media B27. Media B27 supports the neural differentiation of stem cells $[16,17]$. Using microscopy analysis, the morphological changes of the ADSCs after induction with VPA may be tracked photographically and at specific chosen time points. The proteomic analysis provides a broader data pool of the global effect of the VPA, not only on the transcription but also directly on the different neural differentiation pathways by inducing critical interactions. Furthermore, investigation of the proteins critical in VPA induction of the cascade pathways such as MAPK/ERK and JAK/STAT may be undertaken. In addition to proteomics, a BioPlex analysis allows for the investigation of the roles of chemokines and cytokines as a complementary analytical technique. This provides more specific information on the secreted cytokines and their role in the induction of differentiation pathways in the cells [18].

\section{Methods}

\subsection{Cell Culture}

The procedures of adult human ADSCs isolation and expansion were used from Santos et al. [3] utilising cells that were cryo-stored from UTS-HREC Santos-2013000437. All donor participants 
volunteered through informed consent for waste lipoaspirate donation as per ethics guidelines and were de-identified for research purposes (Ethical Code: UTS-HREC Santos-2013000437, Committee: University of Technology Sydney (UTS) Human Research Ethics Committee, Date: 02/07/2013). Generally, ADSCs were cultured in T175 (Nunc, ThermoScientific, Carlsbad, CA, USA) in DMEM Glutmax/F12 Gibco, Life Technologies, Carlsbad, CA, USA) with 10\% foetal bovine serum (FBS, Gibco, Life Technologies, Carlsbad, CA, USA) incubated at $37^{\circ} \mathrm{C}$ at $5 \% \mathrm{CO}_{2}$ ADSCs were passaged three to five times post isolation by stripping the cells with TrypLE Express (12604 Gibco) before being used in differentiation experiments. The cells were seeded on to 6-well plates (Nunc, ThermoScientific, Carlsbad, CA, USA) at approximately 20,000 cells/mL in $5 \mathrm{~mL}$ of DMEM Glutmax/F12 with FBS and maintained till $80 \%$ prior to commencing chemical induction for differentiation.

\subsection{Chemical Induction for Differentiation}

Sub-confluent ADSCs were washed twice in pre-warmed sterile DMEM Glutmax/F12 (Invitrogen). The cells were then cultured for a further $24 \mathrm{~h}$ in a serum-free pre-induction medium consisting of DMEM/F12 (Invitrogen), and 10\% of the final concentration of the added VPA. The media was then replaced after $24 \mathrm{~h}$ with the neuronal inducing media consisting of DMEM/F12 (Invitrogen), and the final optimised concentrations of $0.2 \mathrm{mM}$ VPA. The control cells were maintained in DMEM Glutmax/F12 Gibco, Life Technologies, Carlsbad, CA, USA) with 10\% foetal bovine serum (FBS, Gibco, Life Technologies, Carlsbad, CA, USA) and a further control of ADSCs in B27 for 24 h was also maintained for further comparative analysis.

\subsection{Cell Harvesting Sample Preparation}

The cells were harvested for proteomic analysis by liquid chromatography-tandem mass spectrometry (LC-MS/MS), at the selected time points of $0,3,6$, and $24 \mathrm{~h}$ post-treatment, were completed in biological and technical triplicates. Culture media was collected from each well in $2 \mathrm{~mL}$ Eppendorf tubes and stored at $-80^{\circ} \mathrm{C}$ for later Bioplex, alkaline phosphatase, and Reazurin assays. Cells were rinsed twice in $5 \mathrm{~mL}$ of $1 \times$ phosphate buffered saline (PBS, Merck KGaA, Darmstadt, Germany) for $5 \mathrm{~min}$ each at $37^{\circ} \mathrm{C}$ and aspirated. Cells were then scraped into $1 \mathrm{~mL}$ of $1 \times$ PBS using a cell scraper (Sarstedt, Numbrecht, Germany) liberated cells were collected into an Eppendorf tube and centrifuged at $4000 \times g$ for $10 \mathrm{~min}$. The supernatant was then discarded, and the cell pellets were stored at $-80{ }^{\circ} \mathrm{C}$ till processing.

\subsection{Alkaline Phosphatase Activity Assay}

Alkaline phosphatase (ALP) is widely used as a measure of stem cell proliferative capacity as well as a marker to show pluripotency [19] and a substantial expression increase from basal states is a measure of osteoblastic differentiation [20]. From the collected conditioned media at the chosen time points, $50 \mu \mathrm{L}$ of media was combined with $50 \mu \mathrm{L}$ of 4-nitrophenol phosphate $(p-\mathrm{NNP})$, the substrate for the colorimetric assay, and the absorbance was measured at $405 \mathrm{~nm}$ and recorded on a Tecan spectrophotometer. As ALP is continuously expressed in dividing stem cells, a relative abundance of secreted ALP can be utilized to determine the cell population proliferation in the presence of cell culture additives. Student's t-test was used for statistical analysis, and $p$-values less than 0.05 were considered to be significant.

\subsection{Cytotoxicity Assay}

Similarly, the cytotoxicity assay was completed in triplicate using $100 \mu \mathrm{L}$ aliquots of the collected conditioned media from the chosen time points combined with $10 \mu \mathrm{L}$ of Reazurin from the Alamar blue kit and incubated for $2 \mathrm{~h}$ at $37^{\circ} \mathrm{C}$ in a clear flat bottom 96-well plate. The plate was then scanned on a Tecan spectrophotometer at a measurement wavelength of $575 \mathrm{~nm}$ with a $9 \mathrm{~nm}$ bandwidth and a reference wavelength scan at $600 \mathrm{~nm}$ with a $9 \mathrm{~nm}$ bandwidth. Absorbance vs. time graphs 
were generated to examine the relative cytotoxicity for each time point. Student's t-test was used for statistical analysis, p-values less than 0.05 are considered to be significant.

\subsection{Cytokine and Chemokine Bioplex Analysis}

Bioplex analysis was performed as per Santos et al. [3] with $500 \mu \mathrm{L}$ aliquots collected at timepoints and controls as follows: DMEM control, starve, B27 control, 0, 3, 6, and $24 \mathrm{~h}$. The assay was performed with Bioplex human 27-plex (M50-0KCAF0Y Bio-Rad Laboratories, Hercules, CA, USA). The data analysis was completed in DanteR software (DanteR version 1.0.0.10. R version 2.12.0 The R Foundation for Statistical Computing, Auckland, New Zealand) [21].

\subsection{Cell Lysate Protein Extraction Sample Preparation}

The cell pellets were resuspended in $100 \mu \mathrm{L} 8 \mathrm{M}$ urea (Merck KGaA, Darmstadt, Germany) and $100 \mathrm{mM}$ ammonium bicarbonate (Merck KGaA, Darmstadt, Germany), sonicated for $10 \mathrm{~min}$ at $50 \%$ power at three $10 \mathrm{~s}$ intervals. The samples were then heated to $95^{\circ} \mathrm{C}$ on a heat block for $10 \mathrm{~min}$, then centrifuged for $1 \mathrm{~min}$ at $5000 \times \mathrm{g}$. The solution was then reduced and alkylated by adding a final concentration of $10 \mathrm{mM}$ tributyl-phosphate (TBP, Merck KGaA, Darmstadt, Germany) and $20 \mathrm{mM}$ acrylamide (Merck KGaA, Darmstadt, Germany), then vortexed and spun down on a mini-centrifuge (Qik Spin QS7000 Edwards Instruments) at 2000× $\mathrm{g}$ for $2 \mathrm{~s}$. The samples were incubated for $90 \mathrm{~min}$ at room temperature then quenched with a final concentration of $50 \mathrm{mM}$ dithiothreitol (DTT, Merck KGaA, Darmstadt, Germany)) and again vortexed and spun down on a mini-centrifuge at $2000 \times g$ for $2 \mathrm{~s}$. The samples were then diluted 1:8 in $100 \mathrm{mM}$ ammonium bicarbonate. We then added $0.5 \mu \mathrm{g}$ of trypsin to digest at $37^{\circ} \mathrm{C}$ for a minimum of $12 \mathrm{~h}$. The samples were then desalted using SiliaprepX SCX SPE solid phase extraction columns (Silicycle, Quebec City, Canada). The peptide concentration was determined using the Pierce quantitative colorimetric peptide assay (Thermofisher Scientific, NSW, Australia) and prepared for LC-MS/MS analysis.

\subsection{Liquid Chromatography-Tandem Mass Spectrometry}

An Acquity M-class nanoLC system (Waters, USA) was used, loading $5 \mu \mathrm{L}$ of the sample $(1 \mathrm{mg})$ at a rate of $15 \mathrm{~mL} / \mathrm{min}$ for $3 \mathrm{~min}$ onto a nanoEase Symmetry C18 trapping column $(180 \mathrm{~mm} \times 20 \mathrm{~mm})$. It was then washed onto a PicoFrit column (75 mm ID $\times 250 \mathrm{~mm}$; New Objective, Woburn, MA, USA) packed with Magic C18AQ resin (Michrom Bioresources, Auburn, CA, USA). The column was then eluted of peptides into the Q Exactive Plus mass spectrometer (Thermofisher Scientific, NSW, Australia) using the following program: 5\%-30\% MS buffer B (98\% Acetonitrile $+0.2 \%$ Formic Acid) over 90 min, $30 \%-80 \%$ MS buffer B over $3 \mathrm{~min}, 80 \%$ MS buffer B for $2 \mathrm{~min}, 80 \%-5 \%$ for $3 \mathrm{~min}$. The peptides that were eluted were ionised at $2000 \mathrm{~V}$. A data dependant MS/MS (dd-MS2) experiment was performed, with a 350-1500 Da survey scan was performed at a resolution of 70,000 m/z for peptides of charge state 2+ or higher with an Automatic Gain Control (AGC) target of $3 \times 10^{6}$ and a $50 \mathrm{~ms}$ maximum injection time. The top 12 peptides were selectively fragmented in the Higher-energy collisional dissociation (HCD) cell using a $1.4 \mathrm{~m} / \mathrm{z}$ isolation window, an AGC target of $1 \times 105$ and a $100 \mathrm{~ms}$ maximum injection time. The fragments were scanned in the Orbitrap analyser at a resolution of 17,500 and the product ion fragment masses were measured over a 120-2000 Da mass range. The mass of the precursor peptide was then excluded for $30 \mathrm{~s}$.

\subsection{Mass Spectrometry, Protein Identification and Data Analysis}

The MS/MS data files were searched against the Human Proteome Database and against common contaminants using Peaks Studio version 8.5 with the following parameter settings: fixed modifications: none; variable modifications: propionamide, oxidised methionine, deamidated asparagine; enzyme: semi-trypsin; number of allowed missed cleavages: three; peptide mass tolerance: 30 ppm; MS/MS mass tolerance: $0.1 \mathrm{Da}$; charge states: $2+, 3+$, and $4+$. The search results were filtered to include peptides with a -log10P score (related to P-value) determined by the false discovery rate (FDR) of less 
than $1 \%$, where the score indicates that the decoy database search matches were less than $1 \%$ of the total matches. Each condition was made up of the biological replicates that were treated at the same time, run in triplicate. Data analysis was completed in Microsoft Excel 365, Peaks version 8.5, DanteR (DanteR version 1.0.0.10. R version 2.12.0 The R Foundation for Statistical Computing, Auckland, New Zealand) [21], Cytoscape (version 3.7.1, Cytoscape Consortium, Seattle, WA, USA) [22].

\section{Results}

\subsection{Live Cell Temporal Microscopy during Neurogenic Induction Differentiation of Human ADSCs}

Live cell microscopy is a vital procedure to track cellular morphologies over time during differentiation. The physical attributes in the cell shape and formation of substructures on cells can specify the health status and stage of differentiation relative to the treatment [23]. The ADSC control (Figure 1A) shows non-induced cells at passage 3 at $0 \mathrm{~h}$ with a typical morphology and diffuse growth with wide cell bodies. Figure 1B-D shows the same field of view through time points 3, 6, and $24 \mathrm{~h}$, respectively, displaying the temporal changes occurring in the identical field of view. The treatment with VPA induced morphological and phenotypical changes in the ADSCs resembling differentiating or pre-neural cells. Generally, over time, the cells structural rearrangement shows an adopted bipolar stretched out shape displaying a condensed cell membrane around the nuclear region within the first $3 \mathrm{~h}$. Furthermore, the appearance of dendrite-like structures is also increasingly more apparent from the $6 \mathrm{~h}$ time point and are marked with arrows.

By $24 \mathrm{~h}$, the majority of the cells now display signs of morphological shifts from the control, with a large majority of cells displaying uniform structural changes producing long-extensions between cells and neurite-like outgrowth on some cells. The cell population has remained relatively unchanged across all time points compared to the control, as shown in the average cell counts in Figure 1E. This indicates that minimal to no damage or death due to stress and apoptosis is present in the treated cells.

Supporting the observation of minimal to no damage or death are the graphs in Figure 2 displaying alkaline phosphatase activity on y-axis Figure $2 \mathrm{~A}$ and Reazurin cytotoxicity assay on y-Figure 2B. The ALP column graphs show that the ALP activity decreases marginally in the serum starved cells and for the post VPA treated cells, the similar expression range of ALP confirms the cells are not experiencing osteogenic differentiation secretion levels and that the ALP secretion is maintained within basal levels. The Reazurin cytotoxicity assay line graph shows that the levels at $3 \mathrm{~h}$ post treatment are similar to the pre-treatment values. The stress is marginally increased at 6 and $24 \mathrm{~h}$ however this is lower than the ADSC media change at $24 \mathrm{~h}$, confirming that the VPA treatment has a minimal stress and cytotoxic effect on ADSCs at the treated concentrations relative to controls. Student's t-test analysis revealed no significant change in cell numbers.
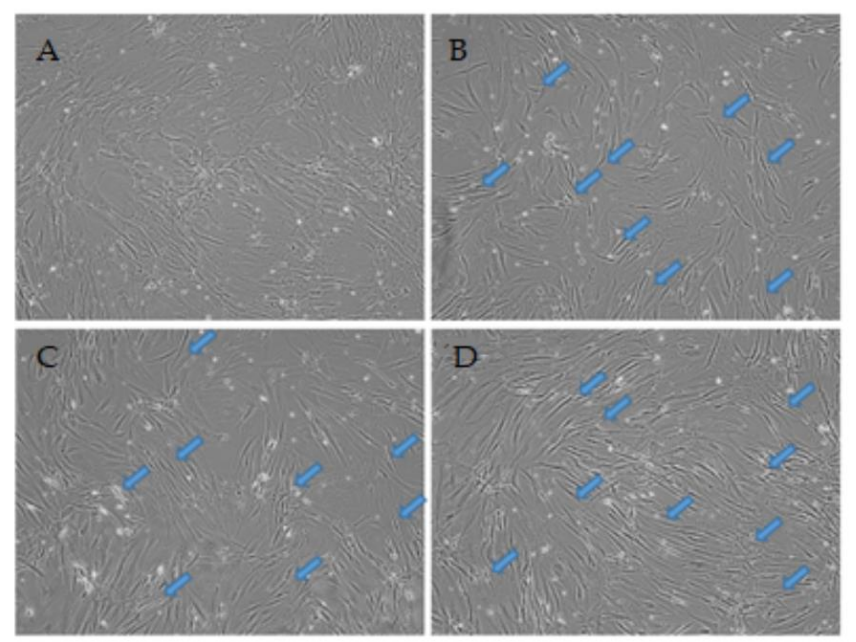

Figure 1. Cont. 
E

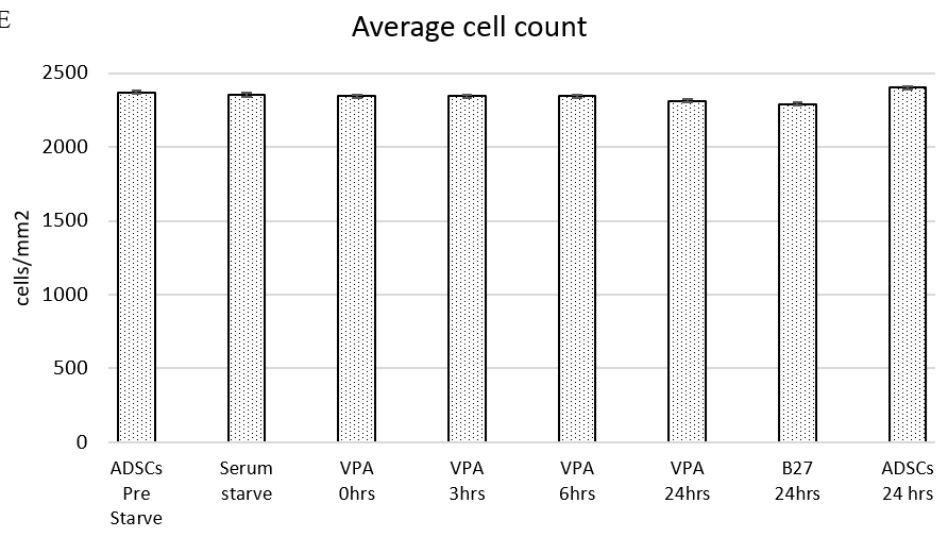

Figure 1. Live cell images of the temporal differentiation of human adipose derived stem cells (ADSCs) induced with $0.2 \mathrm{mM}$ valproic acid (VPA) at (A) $0 \mathrm{~h}$, (B) $3 \mathrm{~h},(\mathbf{C}) 6 \mathrm{~h}$, and (D) $24 \mathrm{~h}$ at $10 \times$ magnification. The cellular morphology changes rapidly through the time points, with cells adopting a more slender and bipolar orientation with neurite extensions (arrows). (E) Average cell count across the treatments including all controls with standard error bars. Relatively minimal changes in numbers are shown across all treatments. A Student's t-test revealed no significant change in cell numbers.

A Alkaline Phosphatase Activity

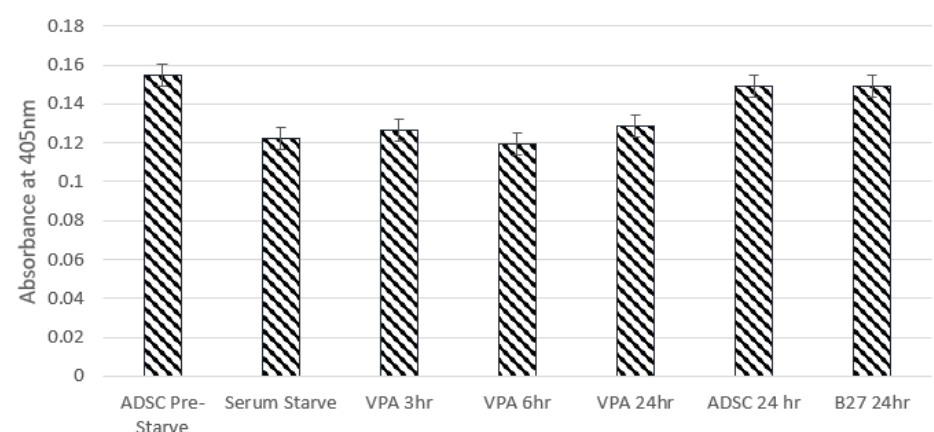

B
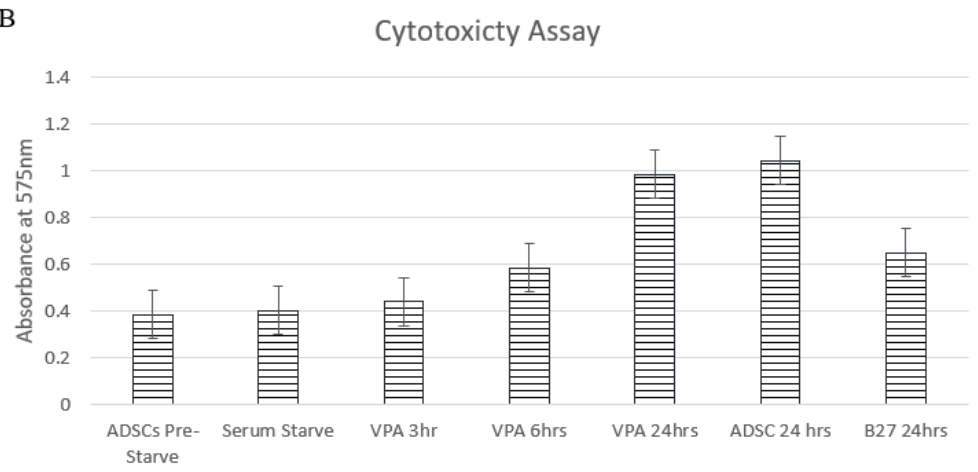

Figure 2. (A) shows the alkaline phosphatase (ALP) activity of cells in each treatment over time. ALP activity decreases marginally after serum starve and remains at relative levels through the treatment time points with standard error bars. There was no significant change seen in the t-test of data. (B) shows the cytotoxicity assay over time as cellular stress was detected by the Reazurin level with standard error bars. Early treatment time points are equivalent to the pre-starved ADSCs prior to treatment. The levels increase from $6 \mathrm{~h}$ and $24 \mathrm{~h}$; however, they remain below ADSCs control at $24 \mathrm{~h}$ and B27 control at $24 \mathrm{~h}$ post media change. There is no statistical significance determined by the t-test.

\subsection{Cytokine and Chemokine Bioplex Analysis}

Cytokines and chemokines are multifunctional molecules with a plethora of roles based on their cellular location. Briefly, some of their roles include, pro-inflammation, anti-inflammation, 
intracellular signalling, intercellular signalling, response to external stimuli, induction or response to protein cascades, and response or guidance of differentiation in cells. Their importance in stem cell differentiation and their response to external stimulation is paramount to clarifying their role in response to VPA. To investigate the relative quantitative changes in the expression and secretion of cytokines and chemokines, the Bioplex multiplex immunoassay was used to simultaneously quantify the molecules in each sample collected from controls and VPA induced time points at 0, 3, 6, and $24 \mathrm{~h}$ (Figure 3). The molecules measured were Eotaxin, Granulocyte-colony stimulating factor (G-CSF), Interferon gamma (IFN- $\gamma$ ), Interleukin IL-1 $\beta$, IL-1ra, IL-2, IL-4, IL-6, IL-7, IL-8, IL-10, IL-12 (p70), IL-13, IL-15, Interferon gamma-induced protein 10 (IP-10), Monocyte Chemoattractant Protein-1 (MCP-1), Macrophage Inflammatory Proteins1 alpha (MIP-1 $\alpha$ ), MIP-1 $\beta$, Tumor necrosis factor alpha (TNF- $\alpha$ ) and Vascular endothelial growth factor (VEGF). From the $3 \mathrm{~h}$ time point post VPA treatment of the ADSCs, there were lower concentrations of all measured molecules with no expression levels of IP-10 and MIP- $1 b$ detected through any successive time points. While most of the other molecules regain some cumulative presence post VPA treatment; IL-1 $\beta$, IL- 6 , and TNF- $\alpha$ demonstrate a marked decrease in levels below the non-treated samples and remain low through all time points with relatively closer levels to the B27 treated cells.

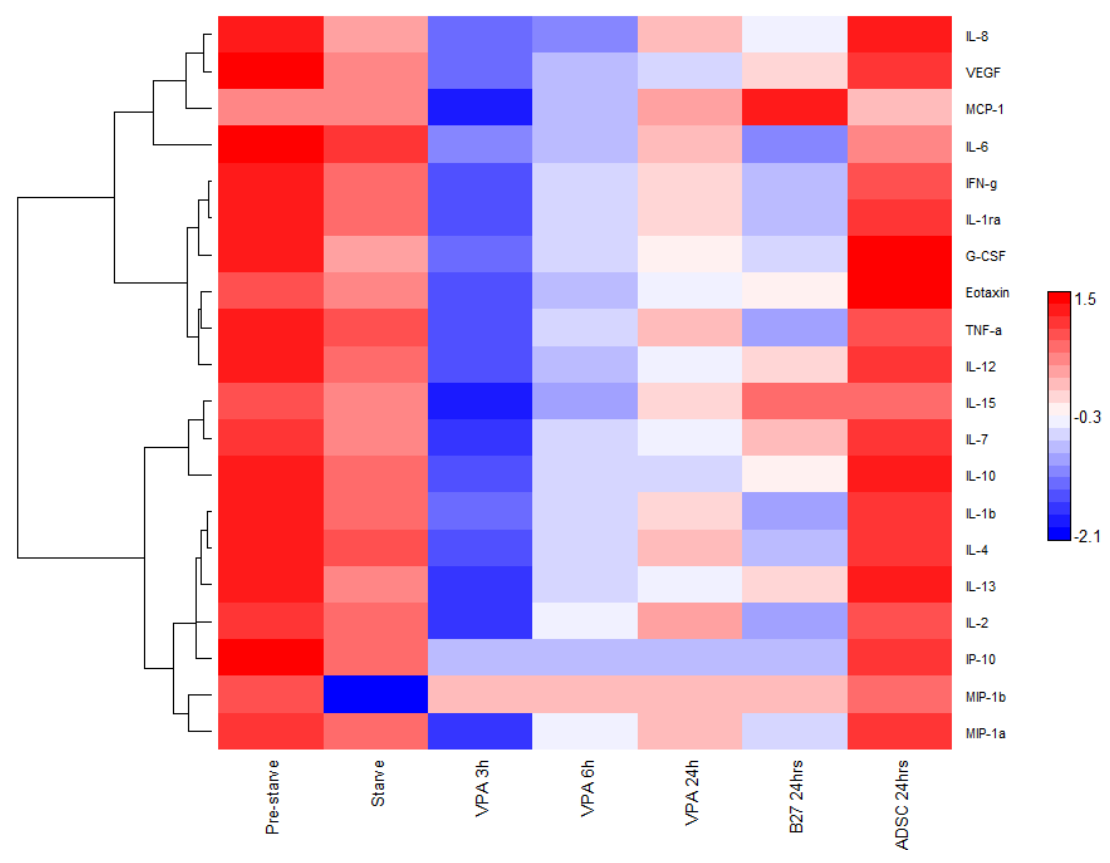

Figure 3. A Bioplex heat map of the log10 measure of cytokines and interleukins expressed in ADSCs in control DMEM media pre FBS starved; starved and in DMEM after $24 \mathrm{~h}$ or treated with B27 or VPA over time. Hierarchical clustering software and a Euclidean test. Red: expression above median; Blue: expression below the median; White: median expression across sample.

\subsection{Proteome Comparisons of VPA Treated Cells}

Each cell treatment was conducted in biological duplicates of tissue cultures. Subsequently, each sample was analysed in technical triplicates by mass spectrometry. This allowed for up to six analysis points for each treatment. This was completed for an increased stringency identification and analysis. Mass spectrometry data compilation (Table 1) identified, at the $95 \%$ confidence cutoff, 2067 unique proteins matched from 20,011 distinct peptides derived from a 344,510 total spectra count (Table 1). There was an average of 2.51 peptides matched per protein with an average of $10 \%$ sequence coverage. Proteins were removed from the analysis if they were identified by less than two quantifiable peptides per protein. The proteins analyzed were uniquely detected per time point or expressed successively through two or more treatment time points. 
Table 1. The number of proteins and peptides identified after liquid chromatography-tandem mass spectrometry analysis of ADSCs and ADSCs treated with VPA.

\begin{tabular}{cccccc}
\hline $\begin{array}{c}\text { Confidence } \\
\text { Cut-off }\end{array}$ & $\begin{array}{c}\text { Proteins } \\
\text { Detected }\end{array}$ & $\begin{array}{c}\text { Proteins Before } \\
\text { Grouping }\end{array}$ & $\begin{array}{c}\text { Distinct } \\
\text { Peptides }\end{array}$ & $\begin{array}{c}\text { Spectra } \\
\text { Identified }\end{array}$ & $\begin{array}{c}\text { \%Total } \\
\text { Spectra }\end{array}$ \\
\hline$>2.0(99)$ & 622 & 765 & 8286 & 313,119 & 66.8 \\
$>1.3(95)$ & 2067 & 2269 & 20,011 & 344,510 & 67.7 \\
$>0.47(66)$ & 2334 & 2460 & 34,492 & 406,322 & 68.5 \\
\hline
\end{tabular}

Interaction network analysis (Figure 4A) using the Cytoscape overlays, the 0, 3, 6 and $24 \mathrm{~h}$ VPA treatment time points combining duplicates and removing proteins with less than two peptides, and post colour-coding for unique and shared proteins, the network displays 1256 proteins with 12,771 interactions. This was completed to locate the date interaction hubs between time points and to visualize the protein pathways. In Figure 4A, the nodes are Blue-ADSC unique, Violet-occurs in two or more time points, Red $-3 \mathrm{~h}$ unique expression, Orange $-6 \mathrm{~h}$ unique expression, and Green-24 $\mathrm{h}$ unique expression. The Venn diagram breakdown (Figure 4B) displays the number of proteins that are unique and shared between each time point as well as percentage of total proteins analysed in the network. The proteins expressed in the ADSC VPA treated time points overlap with only the VPA treated ADSCs total to $3 \mathrm{~h}-221$ proteins, $6 \mathrm{~h}-200$ proteins, and $24 \mathrm{~h}-243$ proteins. The gene ontology analysis of the proteins expressed in the VPA treated ADSCs is graphed in Figure 4C. There are 150 proteins involved across several biological process ontologies aligned with neuron and axon development, projection, differentiation, and cell body morphogenesis.

A

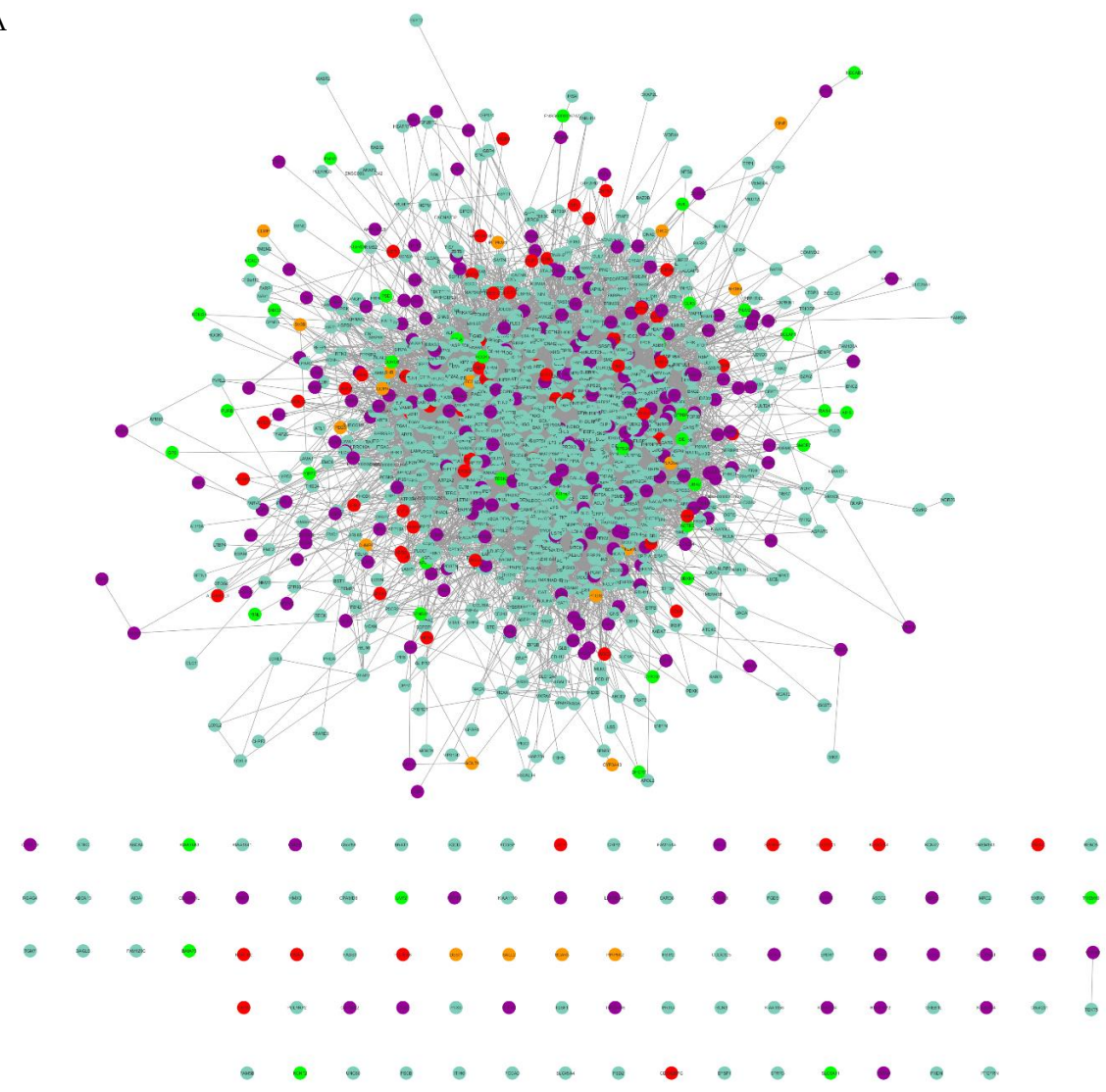

Figure 4. Cont. 


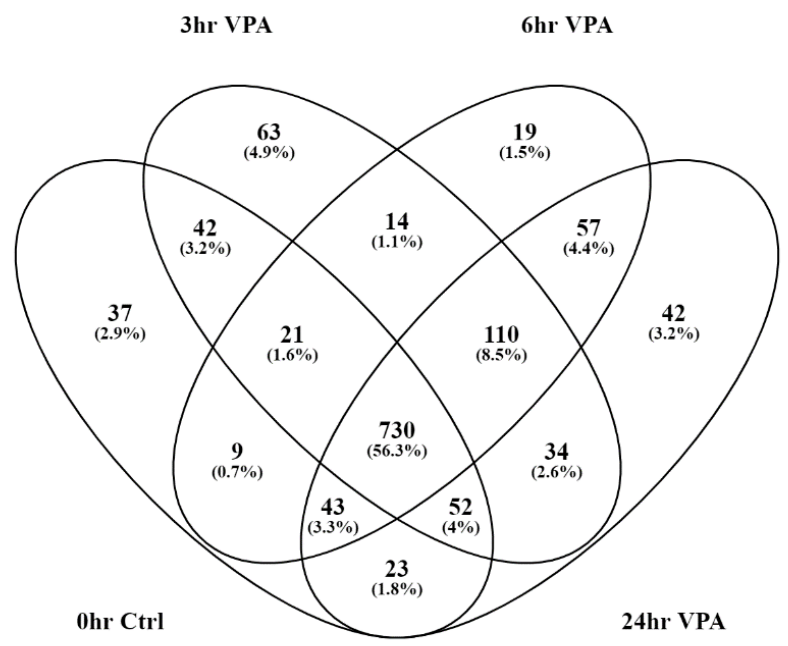

C

\section{Proteins identified with roles in neural development per biological process}

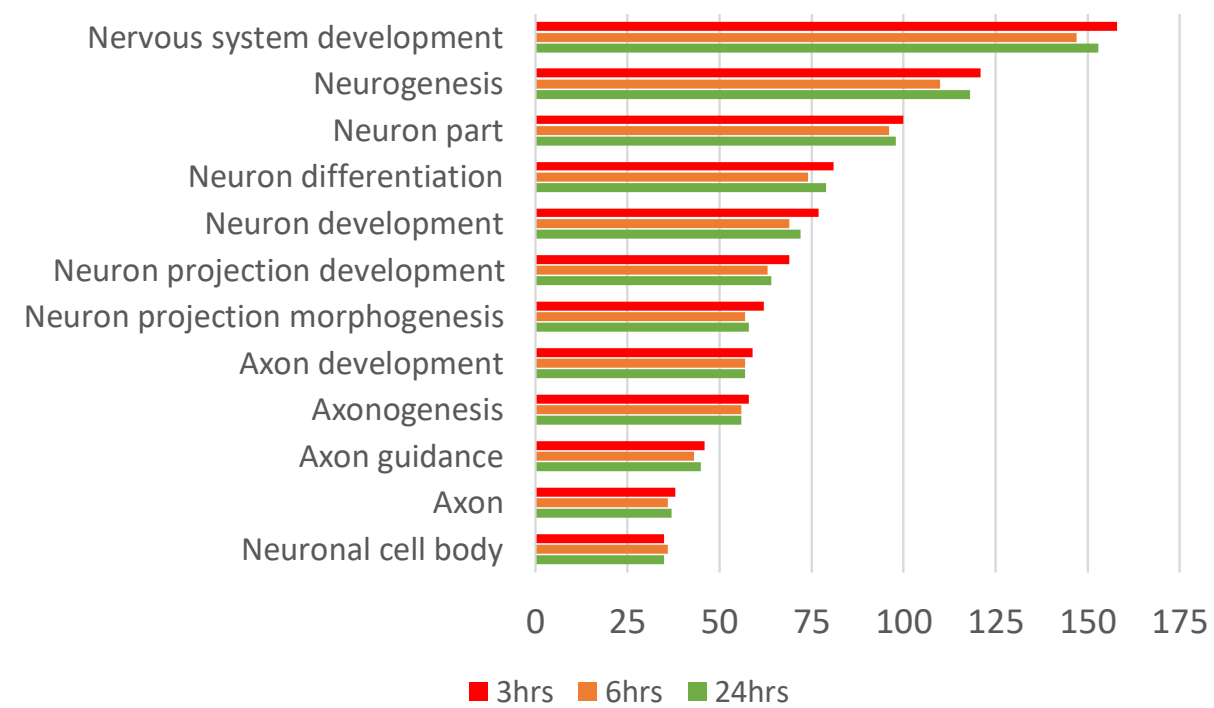

Figure 4. (A) Cytoscape protein interaction network graph of proteins identified by mass spectrometry. Blue-ADSC unique, Violet-occurs in two or more time points, Red-3 h unique expression, Orange-6 $\mathrm{h}$ unique expression, and Green-24 h unique expression. (B) Venn diagram displays breakdown of protein numbers unique and shared between time points. (C) Gene ontology biological process analysis of the proteins expressed in Red $-3 \mathrm{~h}$, Orange $-6 \mathrm{~h}$, and Green $-24 \mathrm{~h}$ shows a high percentage of proteins linked to neural, neuron, or axon development.

\subsection{Pathway Analysis of Gene Ontology Clustered Proteins}

The above-mentioned neural-related proteins identified in gene ontology biological process categories were analysed in ClueGO (version 2.5.4) for group clustering and interaction pathway process analysis (Figure 5). Graphing only the neural-related proteins allowed for a concise interaction map of the probable roles played in the differentiated process as well as links in the signalling pathways. Table 2 breaks down the gene ontology type, number of proteins identified in this dataset as well as the GO term $p$-value Bonferroni step down to validate multiple pair wise tests. 


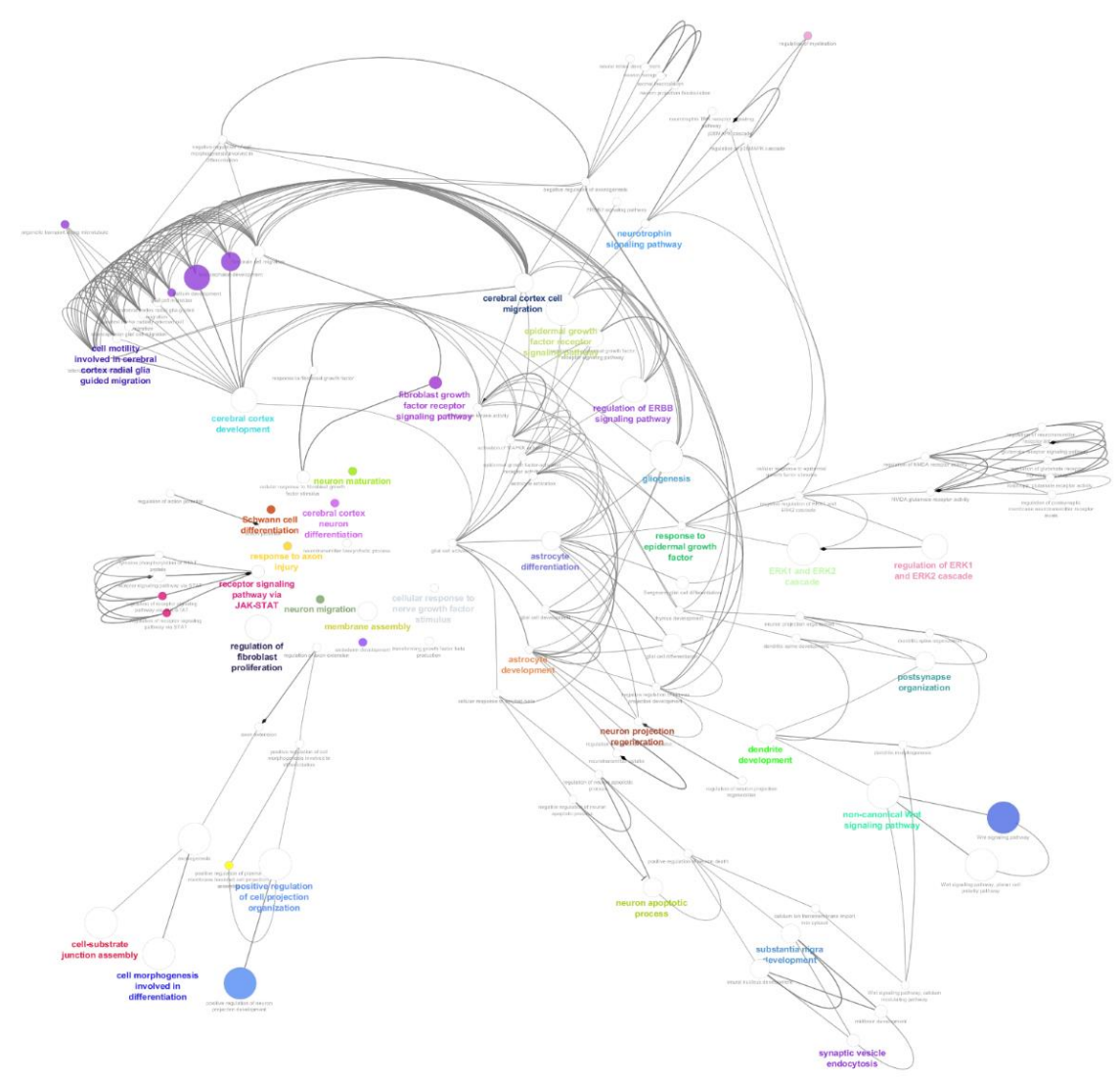

Figure 5. The ClueGo analysis of clustered proteins within each GO node for biological process interaction and signalling pathway analysis involved in the VPA treated cells. Node sizes are relative to number of proteins in dataset identified in that GO. Coloured nodes and labels represent important GO terms in the network.

Figure 6 is a reductive schematic derived from the previous ClueGO graph; it presents the proposed key proteins (summarized in Table 3) and possible summary pathway involved in VPA's action in directing signalling and differentiation in the treated ADSCs. VPA is known to be an HDAC inhibitor, by this direct interaction, HDAC secondary interaction with $\mathrm{H} 1$ and $\mathrm{H} 2 \mathrm{~A}$ is closed. These two proteins have further downstream affects in regulating the RAS/ERK and JAK/STAT pathway via EGRF signalling. By closing this loop, the FGF signalling pathway is upregulated by direct and indirect interactions of VPA which promote the MAPK1 expression and activity. This is a gateway control for initiating the MAPK pathway, which is involved in several neural differentiation lineages. VPA also has an activity in oxidative stress which also acts as a dualistic interaction hub for MAPK pathway promotion.

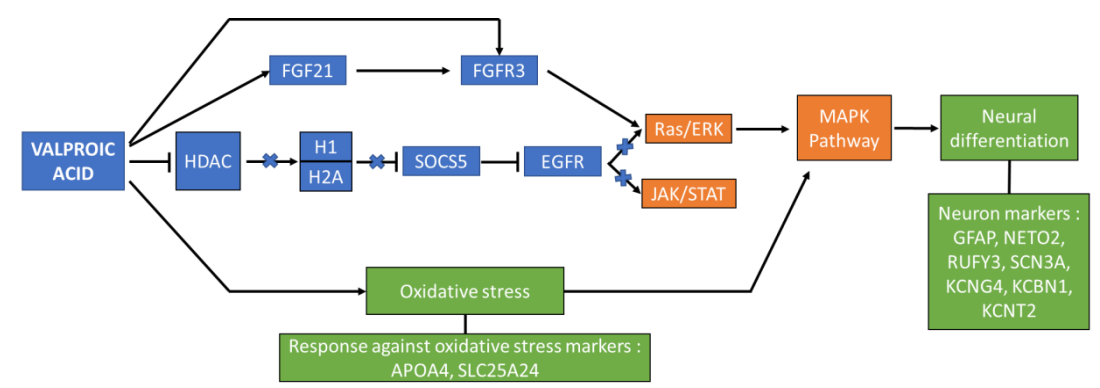

Figure 6. Reductive schematic of the proposed VPA induction pathway in the treatment of ADSCs toward neural differentiation. 
Table 2. The gene ontology of proteins associated in the neural-related ClueGO interaction and signalling network map.

\begin{tabular}{|c|c|c|c|c|c|}
\hline GO Term & GO:ID & $\begin{array}{l}\text { Number of } \\
\text { Proteins }\end{array}$ & Associated Proteins Found & $\begin{array}{l}\text { Percentage of Associated } \\
\text { Proteins in GO }\end{array}$ & Term P-Value \\
\hline $\begin{array}{l}\text { organelle transport along } \\
\text { microtubule }\end{array}$ & GO:0072384 & 5 & [CDC42, LAMP1, SUN1, SYNE2, UCHL1] & 4.72 & $9.03 \times 10^{-3}$ \\
\hline $\begin{array}{l}\text { regulation of NMDA receptor } \\
\text { activity }\end{array}$ & GO:2000310 & 3 & [DLG1, HSPA8, MAPK1] & 5.56 & $2.70 \times 10^{-2}$ \\
\hline $\begin{array}{l}\text { response to fibroblast growth } \\
\text { factor }\end{array}$ & GO:0071774 & 9 & $\begin{array}{l}\text { [CCN2, FGF21, FGF3, FGFR3, MAPK1, POSTN, } \\
\text { PTPN11, TFAP2C, THBS1] }\end{array}$ & 4.95 & $3.59 \times 10^{-4}$ \\
\hline membrane assembly & GO:0071709 & 6 & [ANXA2, CAV1, FLOT1, MAPK1, PDCD6IP, SPTBN1] & 11.54 & $3.57 \times 10^{-5}$ \\
\hline $\begin{array}{l}\text { cell-substrate junction } \\
\text { assembly }\end{array}$ & GO:0007044 & 14 & $\begin{array}{l}\text { [BMX, CTTN, FN1, FYN, LAMB2, LRP1, PLEC, PPM1F, } \\
\text { PTPRK, RAC1, RHOA, ROCK1, THBS1, THY1] }\end{array}$ & 10.22 & $1.08 \times 10^{-9}$ \\
\hline $\begin{array}{l}\text { transforming growth factor } \\
\text { beta production }\end{array}$ & GO:0071604 & 3 & [ITGAV, MTCO2P12, THBS1] & 5.88 & $2.32 \times 10^{-2}$ \\
\hline regulation of myelination & GO:0031641 & 3 & [DLG1, SOS1, TYMP] & 6.12 & $2.09 \times 10^{-2}$ \\
\hline $\begin{array}{l}\text { positive regulation of cell } \\
\text { projection organization }\end{array}$ & GO:0031346 & 24 & $\begin{array}{l}\text { [AP2A1, ARPC2, BMX, CDC42, DDX21, FN1, FSCN1, } \\
\text { FYN, HSPA5, HSPA8, ITGA3, KDM1A, LAP3, LRP1, } \\
\text { NME2, PDCD6IP, PICALM, PSEN1, RAB21, RAC1, } \\
\text { RHOA, SCARB2, SOS1, TMEM30A] }\end{array}$ & 4.60 & $1.90 \times 10^{-8}$ \\
\hline $\begin{array}{l}\text { cellular response to nerve } \\
\text { growth factor stimulus }\end{array}$ & GO:1990090 & 3 & [ARF6, HSPA5, PDCD6IP] & 4.05 & $5.94 \times 10^{-2}$ \\
\hline $\begin{array}{l}\text { cellular response to epidermal } \\
\text { growth factor stimulus }\end{array}$ & GO:0071364 & 5 & [EGFR, GSTP1, PDCD6IP, PTPN11, TFAP2C] & 6.33 & $2.60 \times 10^{-3}$ \\
\hline $\begin{array}{l}\text { neuron projection } \\
\text { regeneration }\end{array}$ & GO:0031102 & 5 & [GFAP, LAMB2, LRP1, SOS1, THY1] & 6.94 & $1.73 \times 10^{-3}$ \\
\hline action potential & GO:0001508 & 8 & $\begin{array}{l}\text { [CACNB3, CAMK2D, CAV1, DLG1, KCNB1, MYH14, } \\
\text { SCN2A, SCN3A] }\end{array}$ & 4.68 & $1.09 \times 10^{-3}$ \\
\hline $\begin{array}{c}\text { regulation of receptor } \\
\text { signalling pathway via STAT }\end{array}$ & GO:1904892 & 8 & [CAV1, FGFR3, FYN, HGS, IL3, JAK3, KLK3, TFRC] & 4.26 & $1.99 \times 10^{-3}$ \\
\hline neurotransmitter uptake & GO:0001504 & 3 & [FLOT1, GFAP, PSEN1] & 4.92 & $3.69 \times 10^{-2}$ \\
\hline
\end{tabular}


Table 2. Cont

\begin{tabular}{|c|c|c|c|c|c|}
\hline GO Term & GO:ID & $\begin{array}{l}\text { Number of } \\
\text { Proteins }\end{array}$ & Associated Proteins Found & $\begin{array}{l}\text { Percentage of Associated } \\
\text { Proteins in GO }\end{array}$ & Term P-Value \\
\hline $\begin{array}{l}\text { cellular response to fibroblast } \\
\text { growth factor stimulus }\end{array}$ & GO:0044344 & 9 & $\begin{array}{c}\text { [CCN2, FGF21, FGF3, FGFR3, MAPK1, POSTN, } \\
\text { PTPN11, TFAP2C, THBS1] }\end{array}$ & 5.26 & $2.26 \times 10^{-4}$ \\
\hline $\begin{array}{l}\text { cellular response to } \\
\text { amyloid-beta }\end{array}$ & GO:1904646 & 5 & [FYN, ICAM1, LRP1, PARP1, PSEN1] & 8.77 & $5.98 \times 10^{-4}$ \\
\hline midbrain development & GO:0030901 & 8 & $\begin{array}{c}\text { [ACTB, CALM2, CDC42, HSPA5, PICALM, POTEF, } \\
\text { RHOA, SOS1] }\end{array}$ & 6.15 & $1.75 \times 10^{-4}$ \\
\hline $\begin{array}{l}\text { response to epidermal growth } \\
\text { factor }\end{array}$ & GO:0070849 & 6 & [EGFR, GSTP1, MAPK1, PDCD6IP, PTPN11, TFAP2C] & 7.14 & $5.19 \times 10^{-4}$ \\
\hline $\begin{array}{l}\text { regulation of neuron } \\
\text { projection regeneration }\end{array}$ & GO:0070570 & 3 & [LRP1, SOS1, THY1] & 7.14 & $1.39 \times 10^{-2}$ \\
\hline regulation of axon extension & GO:0030516 & 5 & [CTTN, FN1, LRP1, RAB21, RTN4] & 4.46 & $1.13 \times 10^{-2}$ \\
\hline $\begin{array}{l}\text { negative regulation of ERK1 } \\
\text { and ERK2 cascade }\end{array}$ & GO:0070373 & 6 & [DLG1, EIF3A, GSTP1, MAPK1, PDCD6IP, TIMP3] & 6.19 & $1.11 \times 10^{-3}$ \\
\hline $\begin{array}{l}\text { negative regulation of neuron } \\
\text { apoptotic process }\end{array}$ & GO:0043524 & 8 & $\begin{array}{c}\text { [BAX, FYN, LRP1, MSH2, PSEN1, RHOA, ROCK1, } \\
\text { TFRC] }\end{array}$ & 4.04 & $2.74 \times 10^{-3}$ \\
\hline $\begin{array}{l}\text { regulation of ERK1 and ERK2 } \\
\text { cascade }\end{array}$ & GO:0070372 & 18 & $\begin{array}{c}\text { [CCN2, DLG1, EGFR, EIF3A, FGF21, FGFR3, FN1, } \\
\text { GNAI2, GSTP1, ICAM1, LRP1, MAPK1, MIF, PDCD6IP, } \\
\text { PPP3CA, PTPN11, TFRC, TIMP3] }\end{array}$ & 4.46 & $1.94 \times 10^{-6}$ \\
\hline $\begin{array}{l}\text { regulation of neuron } \\
\text { apoptotic process }\end{array}$ & GO:0043523 & 11 & $\begin{array}{c}\text { [BAX, FYN, KCNB1, LRP1, MSH2, PARP1, PCSK9, } \\
\text { PSEN1, RHOA, ROCK1, TFRC] }\end{array}$ & 4.03 & $4.76 \times 10^{-4}$ \\
\hline ERK1 and ERK2 cascade & GO:0070371 & 20 & $\begin{array}{l}\text { [CCN2, DLG1, EGFR, EIF3A, FGF21, FGFR3, FN1, } \\
\text { GNAI2, GSTP1, ICAM1, ITGAV, LRP1, MAPK1, MIF, } \\
\text { PDCD6IP, PPP3CA, PTPN11, TFAP2C, TFRC, TIMP3] }\end{array}$ & 4.56 & $3.60 \times 10^{-7}$ \\
\hline glial cell activation & GO:0061900 & 3 & [EGFR, LRP1, PSEN1] & 4.62 & $4.32 \times 10^{-2}$ \\
\hline $\begin{array}{l}\text { telencephalon glial cell } \\
\text { migration }\end{array}$ & GO:0022030 & 4 & [PDCD6IP, RTN4, SUN1, SYNE2] & 9.30 & $1.72 \times 10^{-3}$ \\
\hline telencephalon cell migration & GO:0022029 & 7 & [EGFR, PDCD6IP, PSEN1, RHOA, RTN4, SUN1, SYNE2] & 7.69 & $1.12 \times 10^{-4}$ \\
\hline
\end{tabular}


Table 2. Cont

\begin{tabular}{|c|c|c|c|c|c|}
\hline GO Term & GO:ID & $\begin{array}{l}\text { Number of } \\
\text { Proteins }\end{array}$ & Associated Proteins Found & $\begin{array}{l}\text { Percentage of Associated } \\
\text { Proteins in GO }\end{array}$ & Term P-Value \\
\hline cerebral cortex development & GO:0021987 & 11 & $\begin{array}{c}\text { [ATIC, BAX, EGFR, KDM1A, LRP1, PDCD6IP, PSEN1, } \\
\text { RHOA, RTN4, SUN1, SYNE2] }\end{array}$ & 6.63 & $5.33 \times 10^{-6}$ \\
\hline $\begin{array}{l}\text { cerebral cortex neuron } \\
\text { differentiation }\end{array}$ & GO:0021895 & 3 & [HPRT1, NCOA3, PSEN1] & 7.89 & $1.05 \times 10^{-2}$ \\
\hline forebrain cell migration & GO:0021885 & 7 & [EGFR, PDCD6IP, PSEN1, RHOA, RTN4, SUN1, SYNE2] & 7.45 & $1.37 \times 10^{-4}$ \\
\hline $\begin{array}{l}\text { cell morphogenesis involved } \\
\text { in differentiation }\end{array}$ & GO:0000904 & 37 & $\begin{array}{c}\text { [ARPC2, BMX, CALM2, CAMK2A, CDC42, CTTN, } \\
\text { FAM129B, FLOT1, FN1, FYN, GRB7, HPRT1, } \\
\text { HSP90AA1, ITGAV, KRT7, LAMB2, LRP1, MAPK1, } \\
\text { MYH9, NCOA3, PICALM, POSTN, PPP3CA, PSEN1, } \\
\text { PTPN11, RAB21, RAC1, RB1, RHOA, ROCK1, RTN4, } \\
\text { SOS1, SPTBN1, THY1, TUBB3, UCHL1, VAMP3] }\end{array}$ & 4.03 & $7.39 \times 10^{-11}$ \\
\hline $\begin{array}{l}\text { cell motility involved in } \\
\text { cerebral cortex radial glia } \\
\text { guided migration }\end{array}$ & GO:0021814 & 3 & [PDCD6IP, SUN1, SYNE2] & 18.75 & $8.49 \times 10^{-4}$ \\
\hline $\begin{array}{l}\text { cerebral cortex radial glia } \\
\text { guided migration }\end{array}$ & GO:0021801 & 4 & [PDCD6IP, RTN4, SUN1, SYNE2] & 9.30 & $1.72 \times 10^{-3}$ \\
\hline $\begin{array}{l}\text { cerebral cortex radially } \\
\text { oriented cell migration }\end{array}$ & GO:0021799 & 4 & [PDCD6IP, RTN4, SUN1, SYNE2] & 7.84 & $3.24 \times 10^{-3}$ \\
\hline cerebral cortex cell migration & GO:0021795 & 7 & [EGFR, PDCD6IP, PSEN1, RHOA, RTN4, SUN1, SYNE2] & 9.46 & $2.95 \times 10^{-5}$ \\
\hline glial cell development & GO:0021782 & 7 & [EGFR, GFAP, GSTP1, LAMB2, LRP1, PSEN1, VTA1] & 4.67 & $2.25 \times 10^{-3}$ \\
\hline dendritic spine development & GO:0060996 & 6 & [ARF4, ARF6, CAMK2A, CDC42, MAPK1, PSEN1] & 4.58 & $5.02 \times 10^{-3}$ \\
\hline substantia nigra development & GO:0021762 & 7 & $\begin{array}{r}\text { [ACTB, CALM2, CDC42, HSPA5, PICALM, POTEF, } \\
\text { RHOA] }\end{array}$ & 10.45 & $1.53 \times 10^{-5}$ \\
\hline pallium development & GO:0021543 & 13 & $\begin{array}{l}\text { [ALK, ATIC, ATP2B4, BAX, EGFR, KDM1A, LRP1, } \\
\text { PDCD6IP, PSEN1, RHOA, RTN4, SUN1, SYNE2] }\end{array}$ & 5.31 & $8.59 \times 10^{-6}$ \\
\hline telencephalon development & GO:0021537 & 15 & $\begin{array}{c}\text { [ALK, ATIC, ATP2B4, BAX, EGFR, HPRT1, KDM1A, } \\
\text { LRP1, MAPK1, PDCD6IP, PSEN1, RHOA, RTN4, SUN1, } \\
\text { SYNE2] }\end{array}$ & 4.34 & $1.97 \times 10^{-5}$ \\
\hline
\end{tabular}


Table 2. Cont

\begin{tabular}{|c|c|c|c|c|c|}
\hline GO Term & GO:ID & $\begin{array}{l}\text { Number of } \\
\text { Proteins }\end{array}$ & Associated Proteins Found & $\begin{array}{l}\text { Percentage of Associated } \\
\text { Proteins in GO }\end{array}$ & Term P-Value \\
\hline $\begin{array}{l}\text { epidermal growth } \\
\text { factor-activated receptor } \\
\text { activity }\end{array}$ & GO:0005006 & 4 & [EFEMP1, EGFR, PSEN1, SOCS5] & 9.76 & $1.44 \times 10^{-3}$ \\
\hline $\begin{array}{l}\text { NMDA glutamate receptor } \\
\text { activity }\end{array}$ & GO:0004972 & 3 & [DLG1, HSPA8, MAPK1] & 5.26 & $3.10 \times 10^{-2}$ \\
\hline neuron maturation & GO:0042551 & 3 & [KDM1A, NCOA3, RB1] & 4.41 & $4.83 \times 10^{-2}$ \\
\hline $\begin{array}{l}\text { ionotropic glutamate receptor } \\
\text { activity }\end{array}$ & GO:0004970 & 4 & [DLG1, HSPA8, MAPK1, NETO2] & 4.44 & $2.31 \times 10^{-2}$ \\
\hline activation of MAPKK activity & GO:0000186 & 5 & [EGFR, MAPK1, PDCD6IP, PSEN1, TFRC] & 4.63 & $9.75 \times 10^{-3}$ \\
\hline MAP kinase kinase activity & GO:0004708 & 5 & [EGFR, MAPK1, PDCD6IP, PSEN1, TFRC] & 4.03 & $1.69 \times 10^{-2}$ \\
\hline $\begin{array}{l}\text { Wnt signalling pathway, } \\
\text { planar cell polarity pathway }\end{array}$ & GO:0060071 & 11 & $\begin{array}{c}\text { [AP2A1, AP2A2, AP2B1, CDC42, PDCD6IP, PSMA1, } \\
\text { PSMA3, PSMB9, PSMD4, RAC1, RHOA] }\end{array}$ & 8.09 & $7.54 \times 10^{-7}$ \\
\hline $\begin{array}{l}\text { Bergmann glial cell } \\
\text { differentiation }\end{array}$ & GO:0060020 & 3 & [GFAP, MAPK1, PTPN11] & 33.33 & $1.36 \times 10^{-4}$ \\
\hline dendrite development & GO:0016358 & 14 & $\begin{array}{l}\text { [ARF4, ARF6, CALM2, CAMK2A, CDC42, FYN, HPRT1, } \\
\text { MAPK1, PDCD6IP, PICALM, PPP3CA, PSEN1, RAB21, } \\
\text { RHOA] }\end{array}$ & 4.52 & $2.39 \times 10^{-5}$ \\
\hline neural retina development & GO:0003407 & 3 & [ATP2B4, PSEN1, THY1] & 4.05 & $5.94 \times 10^{-2}$ \\
\hline $\begin{array}{l}\text { neurotransmitter biosynthetic } \\
\text { process }\end{array}$ & GO:0042136 & 6 & $\begin{array}{l}\text { [ATP2B4, CAV1, HSP90AA1, ICAM1, MTCO2P12, } \\
\text { RAC1] }\end{array}$ & 4.84 & $3.84 \times 10^{-3}$ \\
\hline Wnt signalling pathway & GO:0016055 & 25 & $\begin{array}{l}\text { [AP2A1, AP2A2, AP2B1, CALM2, CAMK2A, CAV1, } \\
\text { CDC42, CHD8, CTNND1, EGFR, G3BP1, ITGA3, LRP1, } \\
\text { PDCD6IP, PICALM, PLCB3, PPP3CA, PRKAA1, PSEN1, } \\
\text { PSMA1, PSMA3, PSMB9, PSMD4, RAC1, RHOA] }\end{array}$ & 4.05 & $1.10 \times 10^{-7}$ \\
\hline gliogenesis & GO:0042063 & 18 & $\begin{array}{c}\text { [ANXA1, EGFR, GFAP, GSTP1, KRT7, LAMB2, LRP1, } \\
\text { MAPK1, PDCD6IP, PSEN1, PSMD4, PTPN11, RELA, } \\
\text { RHOA, RTN4, SUN1, SYNE2, VTA1] }\end{array}$ & 4.81 & $6.45 \times 10^{-7}$ \\
\hline
\end{tabular}


Table 2. Cont

\begin{tabular}{|c|c|c|c|c|c|}
\hline GO Term & GO:ID & $\begin{array}{l}\text { Number of } \\
\text { Proteins }\end{array}$ & Associated Proteins Found & $\begin{array}{l}\text { Percentage of Associated } \\
\text { Proteins in GO }\end{array}$ & Term P-Value \\
\hline $\begin{array}{l}\text { regulation of epidermal } \\
\text { growth factor receptor } \\
\text { signalling pathway }\end{array}$ & GO:0042058 & 9 & $\begin{array}{c}\text { [CDC42, EGFR, EPN1, HGS, PDCD6IP, PSEN1, RAB7A, } \\
\text { SOCS5, SOS1] }\end{array}$ & 7.63 & $1.26 \times 10^{-5}$ \\
\hline $\begin{array}{l}\text { neurotrophin signalling } \\
\text { pathway }\end{array}$ & GO:0038179 & 4 & [CTNND1, PDCD6IP, PTPN11, SOS1] & 6.45 & $6.53 \times 10^{-3}$ \\
\hline ERBB2 signalling pathway & GO:0038128 & 4 & [EGFR, GRB7, HSP90AA1, SOS1] & 9.52 & $1.58 \times 10^{-3}$ \\
\hline $\begin{array}{l}\text { regulation of } \\
\text { neurotransmitter uptake }\end{array}$ & GO:0051580 & 3 & [FLOT1, GFAP, PSEN1] & 12.50 & $2.86 \times 10^{-3}$ \\
\hline p38MAPK cascade & GO:0038066 & 4 & [DLG1, PDCD6IP, SOS1, TFAP2C] & 6.56 & $6.16 \times 10^{-3}$ \\
\hline neuron apoptotic process & GO:0051402 & 14 & $\begin{array}{l}\text { [BAX, FYN, HSPA5, KCNB1, LRP1, MSH2, PARP1, } \\
\text { PCSK9, PSEN1, RB1, RHOA, ROCK1, SCN2A, TFRC] }\end{array}$ & 4.50 & $2.47 \times 10^{-5}$ \\
\hline $\begin{array}{c}\begin{array}{c}\text { positive regulation of neuron } \\
\text { death }\end{array} \\
\text {. }\end{array}$ & GO:1901216 & 7 & [BAX, CALM2, FYN, PARP1, PCSK9, PICALM, RHOA] & 5.98 & $5.27 \times 10^{-4}$ \\
\hline Schwann cell differentiation & GO:0014037 & 3 & [LAMB2, RELA, VTA1] & 6.00 & $2.21 \times 10^{-2}$ \\
\hline astrocyte development & GO:0014002 & 5 & [EGFR, GFAP, LAMB2, LRP1, PSEN1] & 8.33 & $7.58 \times 10^{-4}$ \\
\hline $\begin{array}{c}\text { regulation of ERBB signalling } \\
\text { pathway }\end{array}$ & GO:1901184 & 10 & $\begin{array}{l}\text { [CDC42, EGFR, EPN1, HGS, PDCD6IP, PSEN1, RAB7A, } \\
\text { RTN4, SOCS5, SOS1] }\end{array}$ & 7.87 & $3.09 \times 10^{-6}$ \\
\hline $\begin{array}{l}\text { negative regulation of neuron } \\
\text { projection development }\end{array}$ & GO:0010977 & 9 & $\begin{array}{l}\text { [ARF6, GFAP, LRP1, MAPK1, PPP3CA, PSEN1, RHOA, } \\
\text { RTN4, THY1] }\end{array}$ & 4.59 & $6.15 \times 10^{-4}$ \\
\hline $\begin{array}{l}\text { positive regulation of neuron } \\
\text { projection development }\end{array}$ & GO:0010976 & 18 & $\begin{array}{l}\text { [AP2A1, BMX, DDX21, FN1, FYN, HSPA5, HSPA8, } \\
\text { ITGA3, KDM1A, LRP1, NME2, PDCD6IP, PSEN1, } \\
\text { RAB21, RHOA, SCARB2, SOS1, TMEM30A] }\end{array}$ & 4.75 & $7.81 \times 10^{-7}$ \\
\hline $\begin{array}{l}\text { regulation of p38MAPK } \\
\text { cascade }\end{array}$ & GO:1900744 & 3 & [DLG1, PDCD6IP, SOS1] & 6.00 & $2.21 \times 10^{-2}$ \\
\hline $\begin{array}{l}\text { regulation of glutamate } \\
\text { receptor signalling pathway }\end{array}$ & GO:1900449 & 5 & [DLG1, FYN, HSPA8, MAPK1, NETO2] & 5.49 & $4.79 \times 10^{-3}$ \\
\hline
\end{tabular}


Table 2. Cont

\begin{tabular}{|c|c|c|c|c|c|}
\hline GO Term & GO:ID & $\begin{array}{c}\text { Number of } \\
\text { Proteins }\end{array}$ & Associated Proteins Found & $\begin{array}{c}\text { Percentage of Associated } \\
\text { Proteins in GO }\end{array}$ & Term P-Value \\
\hline $\begin{array}{l}\text { non-canonical Wnt signalling } \\
\text { pathway }\end{array}$ & GO:0035567 & 16 & $\begin{array}{l}\text { [AP2A1, AP2A2, AP2B1, CALM2, CAMK2A, CDC42, } \\
\text { PDCD6IP, PICALM, PLCB3, PPP3CA, PSMA1, PSMA3, } \\
\text { PSMB9, PSMD4, RAC1, RHOA] }\end{array}$ & 8.56 & $9.57 \times 10^{-10}$ \\
\hline $\begin{array}{l}\text { negative regulation of cell } \\
\text { morphogenesis involved in } \\
\text { differentiation }\end{array}$ & GO:0010771 & 7 & $\begin{array}{c}\text { [MAPK1, POSTN, PPP3CA, PSEN1, RHOA, RTN4, } \\
\text { THY1] }\end{array}$ & 5.69 & $7.11 \times 10^{-4}$ \\
\hline $\begin{array}{l}\text { positive regulation of cell } \\
\text { morphogenesis involved in } \\
\text { differentiation }\end{array}$ & GO:0010770 & 8 & $\begin{array}{c}\text { [ARPC2, CDC42, FN1, LRP1, NCOA3, RAB21, RAC1, } \\
\text { RHOA] }\end{array}$ & 4.12 & $2.41 \times 10^{-3}$ \\
\hline $\begin{array}{l}\text { negative regulation of } \\
\text { axonogenesis }\end{array}$ & GO:0050771 & 5 & [MAPK1, PSEN1, RHOA, RTN4, THY1] & 5.32 & $5.49 \times 10^{-3}$ \\
\hline $\begin{array}{l}\text { positive regulation of plasma } \\
\text { membrane bounded cell } \\
\text { projection assembly }\end{array}$ & GO:0120034 & 7 & [ARPC2, CDC42, FN1, FSCN1, LAP3, PICALM, RAC1] & 4.64 & $2.33 \times 10^{-3}$ \\
\hline $\begin{array}{l}\text { neuron projection } \\
\text { fasciculation }\end{array}$ & GO:0106030 & 3 & [BMX, MAPK1, RTN4] & 8.57 & $8.40 \times 10^{-3}$ \\
\hline $\begin{array}{l}\text { neuron projection } \\
\text { organization }\end{array}$ & GO:0106027 & 6 & [CDC42, CTTN, FYN, ITGA3, MAPK1, PSEN1] & 4.62 & $4.84 \times 10^{-3}$ \\
\hline neural nucleus development & GO:0048857 & 7 & $\begin{array}{l}\text { [ACTB, CALM2, CDC42, HSPA5, PICALM, POTEF, } \\
\text { RHOA] }\end{array}$ & 7.69 & $1.12 \times 10^{-4}$ \\
\hline $\begin{array}{l}\text { regulation of } \\
\text { neurotransmitter receptor } \\
\text { activity }\end{array}$ & GO:0099601 & 5 & [ATXN2, DLG1, HSPA8, MAPK1, NETO2] & 4.72 & $9.03 \times 10^{-3}$ \\
\hline dendrite morphogenesis & GO:0048813 & 9 & $\begin{array}{l}\text { [CALM2, CAMK2A, CDC42, FYN, HPRT1, MAPK1, } \\
\text { PICALM, PPP3CA, RAB21] }\end{array}$ & 4.48 & $7.36 \times 10^{-4}$ \\
\hline postsynapse organization & GO:0099173 & 12 & $\begin{array}{l}\text { [ACTB, ARF4, ARF6, CDC42, CTTN, DLG1, FYN, } \\
\text { ITGA3, MAPK1, PDCD6IP, POTEF, VTA1] }\end{array}$ & 5.22 & $2.26 \times 10^{-5}$ \\
\hline astrocyte differentiation & GO:0048708 & 8 & $\begin{array}{l}\text { [EGFR, GFAP, KRT7, LAMB2, LRP1, MAPK1, PSEN1, } \\
\text { PTPN11] }\end{array}$ & 7.27 & $5.41 \times 10^{-5}$ \\
\hline
\end{tabular}


Table 2. Cont

\begin{tabular}{|c|c|c|c|c|c|}
\hline GO Term & GO:ID & $\begin{array}{l}\text { Number of } \\
\text { Proteins }\end{array}$ & Associated Proteins Found & $\begin{array}{c}\text { Percentage of Associated } \\
\text { Proteins in GO }\end{array}$ & Term P-Value \\
\hline $\begin{array}{l}\text { regulation of postsynaptic } \\
\text { membrane neurotransmitter } \\
\text { receptor levels }\end{array}$ & GO:0099072 & 5 & [AP2B1, CTNND1, DLG1, HSP90AA1, HSPA8] & 5.56 & $4.57 \times 10^{-3}$ \\
\hline response to axon injury & GO:0048678 & 5 & [ARF4, BAX, GNAI2, LAMB2, LRP1] & 5.15 & $9.03 \times 10^{-3}$ \\
\hline axon extension & GO:0048675 & 7 & [CTTN, FN1, HSP90AA1, LAMB2, LRP1, RAB21, RTN4] & 4.70 & $2.70 \times 10^{-2}$ \\
\hline regulation of action potential & GO:0098900 & 5 & [CACNB3, CAMK2D, CAV1, DLG1, KCNB1] & 7.04 & $3.59 \times 10^{-4}$ \\
\hline thymus development & GO:0048538 & 3 & [MAPK1, PRKDC, PSEN1] & 4.92 & $3.57 \times 10^{-5}$ \\
\hline synaptic vesicle endocytosis & GO:0048488 & 6 & [ACTB, ARF6, CALM2, PICALM, POTEF, ROCK1] & 8.33 & $1.08 \times 10^{-9}$ \\
\hline glial cell differentiation & GO:0010001 & 13 & $\begin{array}{l}\text { [EGFR, GFAP, GSTP1, KRT7, LAMB2, LRP1, MAPK1, } \\
\text { PSEN1, PSMD4, PTPN11, RELA, RHOA, VTA1] }\end{array}$ & 4.74 & $2.32 \times 10^{-2}$ \\
\hline $\begin{array}{l}\text { regulation of fibroblast } \\
\text { proliferation }\end{array}$ & GO:0048145 & 10 & $\begin{array}{c}\text { [ANXA2, BAX, EGFR, FN1, GSTP1, MIF, PDCD6IP, } \\
\text { PML, PPP3CA, PRKDC] }\end{array}$ & 8.06 & $2.09 \times 10^{-2}$ \\
\hline $\begin{array}{l}\text { receptor signalling pathway } \\
\text { via STAT }\end{array}$ & GO:0097696 & 10 & $\begin{array}{c}\text { [CAV1, FGFR3, FYN, HGS, IL3, JAK3, KLK3, SOCS5, } \\
\text { STAT1, TFRC] }\end{array}$ & 4.67 & $1.90 \times 10^{-8}$ \\
\hline astrocyte activation & GO:0048143 & 3 & [EGFR, LRP1, PSEN1] & 9.38 & $5.94 \times 10^{-2}$ \\
\hline $\begin{array}{l}\text { calcium ion transmembrane } \\
\text { import into cytosol }\end{array}$ & GO:0097553 & 9 & $\begin{array}{c}\text { [ATP2B4, BAX, CALM2, CAMK2D, FYN, PICALM, } \\
\text { PLCB3, TFRC, THY1] }\end{array}$ & 4.46 & $2.60 \times 10^{-3}$ \\
\hline $\begin{array}{l}\text { neurotrophin TRK receptor } \\
\text { signalling pathway }\end{array}$ & GO:0048011 & 3 & [CTNND1, PTPN11, SOS1] & 6.38 & $1.73 \times 10^{-3}$ \\
\hline dendritic spine organization & GO:0097061 & 5 & [CDC42, CTTN, FYN, ITGA3, MAPK1] & 4.39 & $1.09 \times 10^{-3}$ \\
\hline $\begin{array}{l}\text { fibroblast growth factor } \\
\text { receptor signalling pathway }\end{array}$ & GO:0008543 & 8 & $\begin{array}{c}\text { [CCN2, FGF21, FGF3, FGFR3, MAPK1, POSTN, } \\
\text { PTPN11, THBS1] }\end{array}$ & 6.15 & $1.99 \times 10^{-3}$ \\
\hline glial cell migration & GO:0008347 & 5 & [LRP1, PDCD6IP, RTN4, SUN1, SYNE2] & 6.58 & $3.69 \times 10^{-2}$ \\
\hline $\begin{array}{c}\text { regulation of receptor } \\
\text { signalling pathway via } \\
\text { JAK-STAT }\end{array}$ & GO:0046425 & 8 & [CAV1, FGFR3, FYN, HGS, IL3, JAK3, KLK3, TFRC] & 4.37 & $2.26 \times 10^{-4}$ \\
\hline neuron recognition & GO:0008038 & 3 & [BMX, MAPK1, RTN4] & 4.55 & $5.98 \times 10^{-4}$ \\
\hline
\end{tabular}


Table 2. Cont.

\begin{tabular}{|c|c|c|c|c|c|}
\hline GO Term & GO:ID & $\begin{array}{l}\text { Number of } \\
\text { Proteins }\end{array}$ & Associated Proteins Found & $\begin{array}{l}\text { Percentage of Associated } \\
\text { Proteins in GO }\end{array}$ & Term P-Value \\
\hline neuron migration & GO:0001764 & 9 & $\begin{array}{l}\text { [BAX, CAMK2A, ELP3, FYN, ITGA3, NAV1, PDCD6IP, } \\
\text { PSEN1, RAC1] }\end{array}$ & 4.39 & $1.75 \times 10^{-4}$ \\
\hline endoderm development & GO:0007492 & 5 & [BPTF, FN1, ITGAV, LAMB2, TFAP2C] & 5.62 & $5.19 \times 10^{-4}$ \\
\hline axonal fasciculation & GO:0007413 & 3 & [BMX, MAPK1, RTN4] & 8.57 & $1.39 \times 10^{-2}$ \\
\hline axonogenesis & GO:0007409 & 24 & $\begin{array}{l}\text { [BMX, CALM2, CTTN, FAM129B, FLOT1, FN1, FYN, } \\
\text { GRB7, HSP90AA1, LAMB2, LRP1, MAPK1, PICALM, } \\
\text { PSEN1, PTPN11, RAB21, RAC1, RHOA, RTN4, SOS1, } \\
\text { SPTBN1, THY1, TUBB3, UCHL1] }\end{array}$ & 4.05 & $1.13 \times 10^{-2}$ \\
\hline $\begin{array}{l}\text { tyrosine phosphorylation of } \\
\text { STAT protein }\end{array}$ & GO:0007260 & 5 & [CAV1, FGFR3, FYN, IL3, JAK3] & 4.72 & $1.11 \times 10^{-3}$ \\
\hline $\begin{array}{l}\text { receptor signalling pathway } \\
\text { via JAK-STAT }\end{array}$ & GO:0007259 & 10 & $\begin{array}{c}\text { [CAV1, FGFR3, FYN, HGS, IL3, JAK3, KLK3, SOCS5, } \\
\text { STAT1, TFRC] }\end{array}$ & 4.81 & $2.74 \times 10^{-3}$ \\
\hline $\begin{array}{l}\text { Wnt signalling pathway, } \\
\text { calcium modulating pathway }\end{array}$ & GO:0007223 & 5 & [CALM2, CAMK2A, PICALM, PLCB3, PPP3CA] & 9.80 & $1.94 \times 10^{-6}$ \\
\hline $\begin{array}{l}\text { glutamate receptor signalling } \\
\text { pathway }\end{array}$ & GO:0007215 & 6 & [DLG1, FYN, HSPA8, KCNB1, MAPK1, NETO2] & 4.62 & $4.76 \times 10^{-4}$ \\
\hline $\begin{array}{l}\text { epidermal growth factor } \\
\text { receptor signalling pathway }\end{array}$ & GO:0007173 & 15 & $\begin{array}{c}\text { [ARF4, CDC42, CTNND1, EFEMP1, EGFR, EPN1, } \\
\text { GRB7, HGS, HSP90AA1, PDCD6IP, PSEN1, PTPN11, } \\
\text { RAB7A, SOCS5, SOS1] }\end{array}$ & 9.20 & $3.60 \times 10^{-7}$ \\
\hline
\end{tabular}


Table 3. Proteins involved in the proposed VPA induction pathway of neural differentiation of ADSCs.

\begin{tabular}{|c|c|c|c|c|c|}
\hline Protein Name & Gene & Accession Numbers & Molecular Weight (Da) & Identification Probability & Gene Ontology \\
\hline $\begin{array}{l}\text { Signal transducer and activator of } \\
\text { transcription 1-alpha/beta }\end{array}$ & STAT1 & P42224 & $87,336.90$ & $100 \%$ & GO:0007259 \\
\hline $\begin{array}{l}\text { Calcium-binding mitochondrial } \\
\text { carrier protein SCaMC-1 }\end{array}$ & SLC25A24 & Q6NUK1-2 & $53,356.60$ & $92.60 \%$ & GO:0034599 \\
\hline Fibroblast growth factor 21 & FGF21 & Q9NSA1 & $22,300.60$ & $92.50 \%$ & GO:0090080 \\
\hline Advillin & AVIL & O75366-2 & $92,029.10$ & $92.20 \%$ & GO:0007399 \\
\hline $\begin{array}{l}\text { Potassium channel subfamily } \mathrm{T} \\
\text { member } 2\end{array}$ & KCNT2 & Q6UVM3-2, Q6UVM3-3 & $130,506.30$ & $89.50 \%$ & GO:0005249 \\
\hline Mitogen-activated protein kinase 1 & MAPK1 & P28482-2 & $41,391.90$ & $86.90 \%$ & GO:0000165 \\
\hline $\begin{array}{l}\text { Neuropilin and tolloid-like protein } \\
2\end{array}$ & NETO2 & Q8NC67-3 & $59,393.90$ & $85.80 \%$ & GO:2000312 \\
\hline Tyrosine-protein kinase JAK3 & JAK3 & P52333-2 & $125,101.70$ & $81.90 \%$ & GO:0046425 \\
\hline Sodium/calcium exchanger 3 & SLC8A3 & $\begin{array}{l}\text { P57103-2, P57103-6, } \\
\text { P57103-7 }\end{array}$ & $103,011.70$ & $77.90 \%$ & GO:0060291 \\
\hline $\begin{array}{l}\text { Signal transducer and activator of } \\
\text { transcription } 6\end{array}$ & STAT6 & P42226 & $94,136.90$ & $59.90 \%$ & GO:0019221 \\
\hline Glial fibrillary acidic protein & GFAP & P14136-2, P14136-3 & $49,881.40$ & $35.40 \%$ & GO:0031102 \\
\hline $\begin{array}{l}\text { Potassium voltage-gated channel } \\
\text { subfamily B member } 1\end{array}$ & KCNB1 & Q14721 & $95,881.40$ & $14.40 \%$ & GO:1900454 \\
\hline $\begin{array}{c}\text { Potassium voltage-gated channel } \\
\text { subfamily G member } 4\end{array}$ & KCNG4 & Q8TDN1 & $58,981.00$ & $11.80 \%$ & GO:0005251 \\
\hline Fibroblast growth factor receptor 3 & FGFR3 & P22607-2 & $877,100.00$ & $6.20 \%$ & GO:0043410 \\
\hline
\end{tabular}




\section{Discussion}

The variety of neural related applications of Valproic acid, including its use as an anticonvulsant to use in treating disorders, such as epilepsy, bipolar, Schizophrenia, Parkinson's, and stroke, holds significant value in its role in directing in vivo neural cell modulation and repair. In vitro studies have observed a VPA effect on several factors in molecular responses of stem cells treated with the chemical, indicating shifts toward neural-like outgrowth with the expression of specific markers and morphological ques associated with differentiation. In this study we aimed to observe and measure the effect of VPA on the wide changes over chosen time points of the proteome of adult stem cells to gain a global understanding of the early mechanisms that are involved in the VPA induction of stem cells.

\subsection{Cellular Morphology}

The microscopy analysis exhibits the first evidence of differentiation. VPA induces morphological changes on the ADSCs within $3 \mathrm{~h}$, and the cells show long cytoplasmic extensions and become thicker relative to the untreated cells. This indicates that VPA may influence cytoskeletal modifications. Dendrite-like structures appear from $6 \mathrm{~h}$ provides further evidence that ADSCs are taking on a neuronal differentiation path. At the final time point, examined at $24 \mathrm{~h}$, the treated cells have a vastly changed appearance from the original form. Much of the population appears slender and has a directed polar outward growth pattern. Furthermore, the dendrite extensions are present in most cells. VPA does not have an influence on the death rate, the cell population has had minimal variation over the treatment time points as opposed to studies with other small chemicals, such as BME and DMSO [2,3,23]. The cell counts and subsequent ALP and Reazurin assays support the stability of the cell culture population with nominal changes over time.

\subsection{Secreted Molecules Role in Signalling Pathways Controlling Neural Differentiation}

The pleiotropic nature of secreted cytokines assists in the molecular signalling and pathway modulation across various systems in almost all cell types. They are particularly interesting due to the multifunctional roles within cellular responses and differentiation, by primarily promoting or closing pathways as well as regulating the expression of specific cascades leading to the release of neurotrophic factors in the case of neural differentiation. Tracking their expression patterns from treated cells utilizing the Bioplex system, allows for a relative quantification and group clustering to identify trends between multiple molecules.

In the Bioplex results, it is noticeable that for almost all cytokines, post VPA treatment, the quantified amounts are reduced from that time point. The levels seem to increase by the final time point with variable expression patterns that are cytokine specific.

We found that VPA has effects on every cytokine measured within this study, thus it has a large action spectrum of modulating cytokine expression, however, is very specific for targets such as IP-10 and MIP-1b. For these two cytokines, IP-10 and MIP-1b, VPA definitively stops their expression upon treatment. IP-10 is not detected after the first control time point across all replicates. This may indicate that VPA has an irreversible action on these particular cytokines. Whereas, the other cytokine trends indicate possible reversible action as variable expression patterns are viewed across time points. IP-10 and MIP-1b have known interactions and roles with the JAK/STAT protein pathway $[24,25]$. The JAK/STAT canonical pathway is a system of linked interactions involved in the phosphorylation of tyrosine residues in receptors creating active binding sites for proteins with Src-Homology (SH2) domains.

In this receptor-SH2 activation the ligand proteins are translocated to the cell nucleus to initiate the transcription of genes that are vital in development, immunity and oncogenesis [26]. MIP-1b and STAT-1 protein interaction were previously implicated in the development of human glial cells and astrocytes [27]. IP-10 has also been shown to play a critical role in the maintenance of maturing astrocytes in vitro [28]. The limitation of these two molecules expression and subsequent interactions 
could limit the astroglial lineage commitment and instead promote neuronal development via the MAPK pathway. Supporting this, astrogliogenesis has been noted to require a high expression of neuroinflammatory cytokines IL-1 $\beta$, IL-6, and TNF- $\alpha$ during the development process [29].

These molecules were detected within the VPA treatments at levels substantially below the non-treated ADSC controls. Higher expression levels of IL-1 $\beta$ [30,31], IL-6 [32] and TNF- $\alpha$ [33] are known to be inhibitory or to limit to neurogenesis as well as promote cellular proliferation. Chen et al., found that increased IL-1 $\beta$ limited neurogenesis by co-stimulation of STAT in the JAK/STAT pathway [34]. Jian et al., noted that the repression of the STAT occurs by activating the MAPK pathway [35], thus supporting the dualistic nature of JAK/STAT versus MAPK. The reduced expression of the abovementioned cytokines by modulation of VPA treatment favours neurogenesis induction over astrogliogenesis.

The expression changes in cytokines involved in one or several pathways like the ERK/MAPK or JAK/STAT pathways affect, even if it is temporally, the pathways and inductive effects on the cellular cycle and the induction of differentiation.

\subsection{Protein Expression and Interaction Pathways Affected by VPA Treatment}

The proteomics and network analysis show that VPA induces the expression of a variety of neural developmental and differentiation related proteins. An interesting protein expressed due to VPA influence is SOCS5. It is found in the $3 \mathrm{~h}$ samples, so the VPA effect on its expression is short; however, its functional role is considerable. SOCS5 is categorised in the protein family group of suppressors of cytokine signalling. SOCS5 gene expression is repressed by histone deacetylation [36], and we know that VPA inhibits class I HDAC [11]. Thus, VPA treatment assists in increasing the expression of SOCS5 by inhibiting the HDAC. Studies proved that SOCS5 inhibits the JAK/STAT pathway [37] by decreasing STATs activation [38]. SOCS5 is also involved in the negative regulation of IL4 and IL7 signalling [38]; this is seen in this studies Bioplex results. The expression of SOCS5 could be one of the responsible elements in decreasing IL4 and IL7 expression and possibly other cytokines. Its effect may only be temporary for most of the cytokines expressions and definitive for IP-10 and MIP- $1 \mathrm{~b}$.

SOCS5 has also been previously annotated to interact with epidermal growth factor receptor (EGFR). EGFR primary binding partner is epidermal growth factor (EGF) which activates several signal transduction pathways including PI3K/AKT, RAS/ERK and JAK/STAT pathways [39]. The role of EGFR is particularly important for maintaining proliferative capacities in cells which is directly promotes JAK/STAT family proteins and dysregulates mTOR pathways useful in downstream neurogenesis. Furthermore, EGFR role in JAK/STAT promotes gliogenesis in direct competitive opposition to the activation of the Ras/ERK-MAPK signalling pathway [40]. The interaction of SOCS5 and EGFR is a SH-2 domain associated inhibition of EGFR, thereby the SOCS5 again has another multifunctional influence on limiting the JAK/STAT pathway [41]. SOCS5 could indirectly activate the MAPK pathway through this pathway alternation. Furthermore, the appearance of JAK3 protein in the last time points could prove that the JAK/STAT is downregulated and an intermediary protein of the cascade of reaction as JAK3 accumulates. The events conducting to this result require further investigation. By this protein interactivity the expression of SOCS5 downregulates the activation of the RAS/ERK and JAK/STAT pathways.

\subsection{The Oxidative Stress Role in Neural Differentiation Activation}

Oxidative stress is another effect of VPA treatment, by increasing the formation of reactive oxygen species [42]. In several case studies, it was noted that increasing levels of oxidative stress can be counterproductive to cellular function; however, there is now a growing body of evidence that indicates that oxidative stress is necessary in neurogenesis [43]. A recent study by Okubo et al. [44] supports VPAs role in modulating oxidative stress by through NO-signalling. The expression of apolipoprotein A-4 (APOA4) is a marker of cellular response against oxidative stress [45]. Similarly, the calcium binding mitochondrial carrier proteins (SLC25A24) is also expressed by the cells to protect themselves 
from oxidative stress [46]. Within the biological process GO graph (Figure 4), these proteins were found to be database annotated [47] in cell differentiation and neuron specific ontologies, namely; generation of neurons, neurogenesis, neuron development and neuron projection development. These ontologies were found to have several subsidiary groupings, examined through the ClueGo interaction map (Figure 5), to specific neuronal developmental checkpoints supported by pathway signalling. The presence of p38 MAPKs allows for the activation of the MAPK cascade and mitotic arrest under a low level of oxidative stress, which has also been reported by Kurata et al. [48]. VPA's role in p38 MAPK expression and the subsequent activation of the MAPK cascade is a supplementary route over the Ras/ERK signalling forbearer activation of MAPK and neurogenesis pathways. VPA creates an environment with low oxidative stress triggering the ADSCs to activating the MAPK cascade.

\subsection{Functional Roles of Identified Neural Proteins in VPA Treated MSCS}

Studies show that VPA promotes the production of Fibroblast growth factor 21 (FGF21) while suppressing HDAC [49]. FGF21 expression in this study was noted onward from the $6 \mathrm{~h}$ time point FGF21 is a regulator of metabolic processes and has strong links to neurogenesis and neuron maturation and myelination [50]. Its receptor FGFR3 is expressed at $3 \mathrm{~h}, 6 \mathrm{~h}$, and $24 \mathrm{~h}$. Studies proved that following the FGF21 activation of FGFR, the MAPK pathway is initiated, involving phosphorylation of ERK 1 and 2 [51]. In the ClueGo analysis, the FGFR signalling pathway is proximal to several downstream processes, particularly in cerebral cortex development and neuron maturation. In a recent study by Shahror et al. [52] it was shown that MSCs over expressing FGF21 transplanted to a mouse model enhanced neurogenesis and recovery. Furthermore, their results also show the FGF21 promoted maturation of the hippocampal neurons. The expression of the FGF21 and FGFR3 post VPA treatment of the stem cells is useful indicator of the neurogenic potential of VPA and MSCs.

A pertinent dataset, supportive of neuronal induction and differentiation, is the presence of neuronal markers, which appear from the first treatment time point. Table 2 presents a list of identified proteins and their correlative biological process in neurodevelopment according to gene ontology. Exploring several key markers and their interaction partners allows for a greater view of the molecular changes occurring during treatment and differentiation. The early expression of glial fibril associated protein (GFAP), neuropilin and tolloid like 2 (NETO2), and RUN and FYVE Domain Containing 3 (RUFY3) are particularly interesting. GFAP is known to be expressed in developing central nervous systems, and is particularly expressed in glia, astrocytes, neural stem cells, and neuron progenitor cells, with its expression declining in mature neurons [53].

It plays a vital role in neuron development, and is classed in the GO category of neuron projections along with its GO category and interaction partner, Thy1-membrane glycoprotein (THY1). The interaction of these two proteins are thought to guide cell-to-cell extension in the early phases of synapse formation. The expression of NETO2 and RUFY3 were of great interest as these proteins were annotated as specifically expressed in neurons [54,55]. NETO2 interacts with several other proteins and falls in with certain ontologies related to neurotransmitter update and glutamate receptor regulation. NETO2 is also known to assist in the development of neurite outgrowth [55].

RUFY3 is also involved in the growth of neurons, specifically associated with the guidance of axon growth [54], fittingly, the ontologies analysis and graphs correlate its role in neuron development, the positive regulation of cell morphogenesis involved in differentiation, and the regulation of neuron projection development. Their presence in this study of treated stem cell samples eludes to the early stages of differentiation and commitment toward neuronal lineage. Some markers appear in later time points like advillin (AVIL) and proteins involved in voltage-gated channel and that are specific in generating the neuronal action potential, such as SCN3A, KCNG4, KCBN1 and KCNT2. AVIL is involved in neuron development by cytoskeletal organization in neuron projection and morphogenesis through its interaction with intermediary filaments and is a downstream partner in the MAPK pathway. These proteins are evidentiary developing neuron markers. Their presence in the VPA treated ADSCs shows that the cells are following a neuronal differentiation pathway. 


\section{Conclusions}

In this study we presented the temporal treatment of VPA on ADSCs and the proteomic, Bioplex, interaction network and pathway analysis. We found that VPA induces a cascade of reactions using its different properties. Inhibiting HDACs, it promotes the expression of SOCS5, which downregulates the JAK/STAT pathway. In this way, the glial differentiation is silenced, and the neuronal differentiation can be promoted.

We demonstrated that VPA activates the MAPK cascade by creating a low oxidative stress and by upregulating the expression of FGF21. However, the ERK pathway is downregulated by SOCS5 as well; however, this can operate as a regulator of the activation of the ERK/MAPK cascade. Specific neuronal markers are found in the induced ADSCs and their expressions confirm that VPA induced a neuronal differentiation pathway on the ADSCs.

This study opens a new opportunity to further differentiate ADSCs into neurons using a chemical that is already used clinically. VPA can be a key to finding new neuro-regenerative methods.

Author Contributions: J.S. conceived and designed the experiments. T.H. performed cell culture, differentiation cell preparation for mass spectrometry. J.S. performed Bioplex and assays. J.S., T.H. and B.K.M. analyzed data and wrote paper. B.K.M. contributed reagents/materials, edited paper and supervised J.S. and T.H. All authors have read and agreed to the published version of the manuscript.

Funding: This research was partially funded by the Schwartz Foundation philanthropic donation to support research.

Acknowledgments: We would like to thank the UTS Proteomics Core Facility, Matt Padula for technical support and running samples on the Mass spectrometer.

Conflicts of Interest: The authors declare no conflict of interest.

\section{Abbreviations}

$\begin{array}{ll}\text { ADSCs } & \text { Adipose Derived Stem Cells } \\ \text { ALP } & \text { Alkaline phosphatase } \\ \text { AVIL } & \text { Advillin } \\ \text { BHA } & \text { butylated hydroxyanisole } \\ \text { BME } & \text { beta-mercaptoethanol } \\ \text { DMEM } & \text { Dulbecco's Modified Eagle's Medium: Nutrient Mixture F-12 } \\ \text { DMSO } & \text { dimethylsulfoxide } \\ \text { ERK } & \text { Extracellular Receptor Kinase } \\ \text { FGF21 } & \text { Fibroblast growth factor 21 } \\ \text { FGFR3 } & \text { Fibroblast growth factor receptor 3 } \\ \text { GFAP } & \text { Glial fibrillary acidic protein } \\ \text { hADSCs } & \text { human Adipose Derived Stem Cells } \\ \text { HDAC } & \text { histone deacetylase } \\ \text { JAK } & \text { Janus kinase } \\ \text { JAK3 } & \text { Tyrosine-protein kinase JAK3 } \\ \text { KCNB1 } & \text { Potassium voltage-gated channel subfamily B member 1 } \\ \text { KCNG4 } & \text { Potassium voltage-gated channel subfamily G member 4 } \\ \text { KCNT2 } & \text { Potassium channel subfamily T member 2 } \\ \text { LC-MS/MS } & \text { Liquid chromatography tandem mass spectrometry } \\ \text { MAPK1 } & \text { Mitogen-activated protein kinase } \\ \text { NETO2 } & \text { Neuropilin and tolloid-like protein 2 } \\ \text { PBS } & \text { Phosphate-buffered saline } \\ \text { RA } & \text { Retinoic acid } \\ \text { SLC25A24 } & \text { Calcium-binding mitochondrial carrier protein SCaMC-1 } \\ \text { SLC8A3 } & \text { Sodium/calcium exchanger 3 } \\ \text { STAT1 } & \text { Signal transducer and activator of transcription 1-alpha/beta } \\ \text { STAT6 } & \text { Signal transducer and activator of transcription 6 } \\ \text { VPA } & \text { Valproic Acid } \\ & \end{array}$




\section{References}

1. Franco Lambert, A.P.; Fraga Zandonai, A.; Bonatto, D.; Cantarelli Machado, D.; Pegas Henriques, J.A. Differentiation of human adipose-derived adult stem cells into neuronal tissue: Does it work? Differ. Res. Biol. Divers. 2009, 77, 221-228. [CrossRef]

2. Woodbury, D.; Schwarz, E.J.; Prockop, D.J.; Black, I.B. Adult rat and human bone marrow stromal cells differentiate into neurons. J. Neurosci. Res. 2000, 61, 364-370. [CrossRef]

3. Santos, J.; Milthorpe, B.K.; Herbert, B.R.; Padula, M.P. Proteomic Analysis of Human Adipose Derived Stem Cells during Small Molecule Chemical Stimulated Pre-neuronal Differentiation. Int. J. Stem Cells 2017. [CrossRef]

4. Kondo, T.; Johnson, S.A.; Yoder, M.C.; Romand, R.; Hashino, E. Sonic hedgehog and retinoic acid synergistically promote sensory fate specification from bone marrow-derived pluripotent stem cells. Proc. Natl. Acad. Sci. USA 2005, 102, 4789-4794. [CrossRef]

5. Yu, J.M.; Bunnell, B.A.; Kang, S.K. Neural differentiation of human adipose tissue-derived stem cells. Methods Mol. Biol. (Clifton, N.J.) 2011, 702, 219-231. [CrossRef]

6. Mu, M.W.; Zhao, Z.Y.; Li, C.G. Comparative study of neural differentiation of bone marrow mesenchymal stem cells by different induction methods. Genet. Mol. Res. GMR 2015, 14, 14169-14176. [CrossRef] [PubMed]

7. Santos, J.; Milthorpe, B.K.; Padula, M.P. Proteomic Analysis of Cyclic Ketamine Compounds Ability to Induce Neural Differentiation in Human Adult Mesenchymal Stem Cells. Int. J. Mol. Sci. 2019, 20, 523. [CrossRef] [PubMed]

8. Talwadekar, M.; Fernandes, S.; Kale, V.; Limaye, L. Valproic acid enhances the neural differentiation of human placenta derived-mesenchymal stem cells in vitro. J. Tissue Eng. Regen. Med. 2017, 11, 3111-3123. [CrossRef] [PubMed]

9. Vukicevic, V.; Qin, N.; Balyura, M.; Eisenhofer, G.; Wong, M.L.; Licinio, J.; Bornstein, S.R.; Ehrhart-Bornstein, M. Valproic acid enhances neuronal differentiation of sympathoadrenal progenitor cells. Mol. Psychiatry 2015, 20, 941-950. [CrossRef]

10. Eckschlager, T.; Plch, J.; Stiborova, M.; Hrabeta, J. Histone Deacetylase Inhibitors as Anticancer Drugs. Int. J. Mol. Sci. 2017, 18, 1414. [CrossRef]

11. Gottlicher, M.; Minucci, S.; Zhu, P.; Kramer, O.H.; Schimpf, A.; Giavara, S.; Sleeman, J.P.; Lo Coco, F.; Nervi, C.; Pelicci, P.G.; et al. Valproic acid defines a novel class of HDAC inhibitors inducing differentiation of transformed cells. EMBO J. 2001, 20, 6969-6978. [CrossRef] [PubMed]

12. Yu, I.T.; Park, J.-Y.; Kim, S.H.; Lee, J.-S.; Kim, Y.-S.; Son, H. Valproic acid promotes neuronal differentiation by induction of proneural factors in association with H4 acetylation. Neuropharmacology 2009, 56, 473-480. [CrossRef]

13. Hsieh, J.; Nakashima, K.; Kuwabara, T.; Mejia, E.; Gage, F.H. Histone deacetylase inhibition-mediated neuronal differentiation of multipotent adult neural progenitor cells. Proc. Natl. Acad. Sci. USA 2004, 101, 16659-16664. [CrossRef] [PubMed]

14. Liu, X.S.; Chopp, M.; Kassis, H.; Jia, L.F.; Hozeska-Solgot, A.; Zhang, R.L.; Chen, C.; Cui, Y.S.; Zhang, Z.G. Valproic acid increases white matter repair and neurogenesis after stroke. Neuroscience 2012, 220, 313-321. [CrossRef] [PubMed]

15. Rezaei, F.; Tiraihi, T.; Abdanipour, A.; Hassoun, H.K.; Taheri, T. Immunocytochemical analysis of valproic acid induced histone $\mathrm{H} 3$ and $\mathrm{H} 4$ acetylation during differentiation of rat adipose derived stem cells into neuron-like cells. Biotech. Histochem. 2018, 93, 589-600. [CrossRef] [PubMed]

16. Long, X.; Olszewski, M.; Huang, W.; Kletzel, M. Neural cell differentiation in vitro from adult human bone marrow mesenchymal stem cells. Stem Cells Dev. 2005, 14, 65-69. [CrossRef] [PubMed]

17. Tomita, M.; Mori, T.; Maruyama, K.; Zahir, T.; Ward, M.; Umezawa, A.; Young, M.J. A comparison of neural differentiation and retinal transplantation with bone marrow-derived cells and retinal progenitor cells. Stem Cells (Dayton, Ohio) 2006, 24, 2270-2278. [CrossRef]

18. Galindo, L.T.; Filippo, T.R.M.; Semedo, P.; Ariza, C.B.; Moreira, C.M.; Camara, N.O.S.; Porcionatto, M.A. Mesenchymal Stem Cell Therapy Modulates the Inflammatory Response in Experimental Traumatic Brain Injury. Neurol. Res. Int. 2011, 2011, 564089. [CrossRef]

19. Štefková, K.; Procházková, J.; Pacherník, J. Alkaline phosphatase in stem cells. Stem Int. 2015, $2015,628368$. [CrossRef] 
20. Hanna, H.; Mir, L.M.; Andre, F.M. In vitro osteoblastic differentiation of mesenchymal stem cells generates cell layers with distinct properties. Stem Cell Res. Ther. 2018, 9, 203. [CrossRef]

21. Taverner, T.; Karpievitch, Y.V.; Polpitiya, A.D.; Brown, J.N.; Dabney, A.R.; Anderson, G.A.; Smith, R.D. DanteR: An extensible R-based tool for quantitative analysis of -omics data. Bioinformatics 2012, 28, 2402-2406. [CrossRef] [PubMed]

22. Shannon, P.; Markiel, A.; Ozier, O.; Baliga, N.S.; Wang, J.T.; Ramage, D.; Amin, N.; Schwikowski, B.; Ideker, T. Cytoscape: A software environment for integrated models of biomolecular interaction networks. Genome Res. 2003, 13, 2498-2504. [CrossRef]

23. Lu, P.; Blesch, A.; Tuszynski, M.H. Induction of bone marrow stromal cells to neurons: Differentiation, transdifferentiation, or artifact? J. Neurosci. Res. 2004, 77, 174-191. [CrossRef] [PubMed]

24. Wang, W.; Tan, J.; Xing, Y.; Kan, N.; Ling, J.; Dong, G.; Liu, G.; Chen, H. p43 induces IP-10 expression through the JAK-STAT signaling pathway in HMEC-1 cells. Int. J. Mol. Med. 2016, 38, 1217-1224. [CrossRef] [PubMed]

25. Moshapa, F.T.; Riches-Suman, K.; Palmer, T.M. Therapeutic Targeting of the Proinflammatory IL-6-JAK/STAT Signalling Pathways Responsible for Vascular Restenosis in Type 2 Diabetes Mellitus. Cardiol. Res. Pract. 2019, 2019, 9846312. [CrossRef]

26. Jatiani, S.S.; Baker, S.J.; Silverman, L.R.; Reddy, E.P. JAK/STAT Pathways in Cytokine Signaling and Myeloproliferative Disorders: Approaches for Targeted Therapies. Genes Cancer 2010, 1, 979-993. [CrossRef]

27. Rezaie, P.; Trillo-Pazos, G.; Everall, I.P.; Male, D.K. Expression of beta-chemokines and chemokine receptors in human fetal astrocyte and microglial co-cultures: Potential role of chemokines in the developing CNS. Glia 2002, 37, 64-75. [CrossRef]

28. Choi, S.S.; Lee, H.J.; Lim, I.; Satoh, J.-I.; Kim, S.U. Human Astrocytes: Secretome Profiles of Cytokines and Chemokines. PLoS ONE 2014, 9, e92325. [CrossRef]

29. Wang, T.; Yuan, W.; Liu, Y.; Zhang, Y.; Wang, Z.; Zhou, X.; Ning, G.; Zhang, L.; Yao, L.; Feng, S.; et al. The role of the JAK-STAT pathway in neural stem cells, neural progenitor cells and reactive astrocytes after spinal cord injury. Biomed. Rep. 2015, 3, 141-146. [CrossRef]

30. Boehme, M.; Guenther, M.; Stahr, A.; Liebmann, M.; Jaenisch, N.; Witte, O.W.; Frahm, C. Impact of indomethacin on neuroinflammation and hippocampal neurogenesis in aged mice. Neurosci. Lett. 2014, 572, 7-12. [CrossRef]

31. Koo, J.W.; Duman, R.S. IL-1 $\beta$ is an essential mediator of the antineurogenic and anhedonic effects of stress. Proc. Natl. Acad. Sci. USA 2008, 105, 751-756. [CrossRef] [PubMed]

32. Monje, M.L.; Toda, H.; Palmer, T.D. Inflammatory blockade restores adult hippocampal neurogenesis. Science 2003, 302, 1760-1765. [CrossRef] [PubMed]

33. Johansson, S.; Price, J.; Modo, M. Effect of Inflammatory Cytokines on Major Histocompatibility Complex Expression and Differentiation of Human Neural Stem/Progenitor Cells. Stem Cells (Dayton, Ohio) 2008, 26, 2444-2454. [CrossRef] [PubMed]

34. Chen, E.; Xu, D.; Lan, X.; Jia, B.; Sun, L.; Zheng, J.C.; Peng, H. A Novel Role of the STAT3 Pathway in Brain Inflammation-induced Human Neural Progenitor Cell Differentiation. Curr. Mol. Med. 2013, 13, 1474-1484. [CrossRef]

35. Jain, N.; Zhang, T.; Fong, S.L.; Lim, C.P.; Cao, X. Repression of Stat3 activity by activation of mitogen-activated protein kinase (MAPK). Oncogene 1998, 17, 3157-3167. [CrossRef]

36. Kim, M.-H.; Kim, M.-S.; Kim, W.; Kang, M.A.; Cacalano, N.A.; Kang, S.-B.; Shin, Y.-J.; Jeong, J.-H. Suppressor of Cytokine Signaling (SOCS) Genes Are Silenced by DNA Hypermethylation and Histone Deacetylation and Regulate Response to Radiotherapy in Cervical Cancer Cells. PLoS ONE 2015, 10, e0123133. [CrossRef]

37. Cooney, R.N. Suppressors of cytokine signaling (SOCS): Inhibitors of the JAK/STAT pathway. Shock (Augusta, Ga.) 2002, 17, 83-90. [CrossRef]

38. Sharma, N.; Nickl, C.; Kang, H.; Winter, S.S.; Cannon, J.; Matlawska-Wasowska, K. SOCS5 Regulates JAK-STAT Signaling and T-ALL Development. Blood 2017, 130, 370.

39. Henson, E.S.; Gibson, S.B. Surviving cell death through epidermal growth factor (EGF) signal transduction pathways: Implications for cancer therapy. Cell. Signal. 2006, 18, 2089-2097. [CrossRef]

40. Bonni, A.; Sun, Y.; Nadal-Vicens, M.; Bhatt, A.; Frank, D.A.; Rozovsky, I.; Stahl, N.; Yancopoulos, G.D.; Greenberg, M.E. Regulation of gliogenesis in the central nervous system by the JAK-STAT signaling pathway. Science 1997, 278, 477-483. [CrossRef] 
41. Kario, E.; Marmor, M.D.; Adamsky, K.; Citri, A.; Amit, I.; Amariglio, N.; Rechavi, G.; Yarden, Y. Suppressors of cytokine signaling 4 and 5 regulate epidermal growth factor receptor signaling. J. Biol. Chem. 2005, 280, 7038-7048. [CrossRef] [PubMed]

42. Tung, E.W.; Winn, L.M. Valproic acid increases formation of reactive oxygen species and induces apoptosis in postimplantation embryos: A role for oxidative stress in valproic acid-induced neural tube defects. Mol. Pharmacol. 2011, 80, 979-987. [CrossRef] [PubMed]

43. Yuan, T.-F.; Gu, S.; Shan, C.; Marchado, S.; Arias-Carrión, O. Oxidative Stress and Adult Neurogenesis. Stem Cell Rev. Rep. 2015, 11, 706-709. [CrossRef] [PubMed]

44. Okubo, T.; Fujimoto, S.; Hayashi, D.; Suzuki, T.; Sakaue, M.; Miyazaki, Y.; Tanaka, K.; Usami, M.; Takizawa, T. Valproic acid promotes mature neuronal differentiation of adipose tissue-derived stem cells through iNOS-NO-sGC signaling pathway. Nitric Oxide 2019, 93, 1-5. [CrossRef] [PubMed]

45. Han, E.-S.; Muller, F.L.; Pérez, V.I.; Qi, W.; Liang, H.; Xi, L.; Fu, C.; Doyle, E.; Hickey, M.; Cornell, J.; et al. The in vivo gene expression signature of oxidative stress. Physiol. Genom. 2008, 34, 112-126. [CrossRef] [PubMed]

46. Traba, J.; Del Arco, A.; Duchen, M.R.; Szabadkai, G.; Satrustegui, J. SCaMC-1 promotes cancer cell survival by desensitizing mitochondrial permeability transition via ATP/ADP-mediated matrix $\mathrm{Ca}(2+)$ buffering. Cell Death Differ. 2012, 19, 650-660. [CrossRef]

47. Mi, H.; Muruganujan, A.; Ebert, D.; Huang, X.; Thomas, P.D. PANTHER version 14: More genomes, a new PANTHER GO-slim and improvements in enrichment analysis tools. Nucleic Acids Res. 2018, 47, D419-D426. [CrossRef]

48. Kurata, S.-I. Selective Activation of p38 MAPK Cascade and Mitotic Arrest Caused by Low Level Oxidative Stress. J. Biol. Chem. 2000, 275, 23413-23416. [CrossRef]

49. Leng, Y.; Wang, J.; Wang, Z.; Liao, H.M.; Wei, M.; Leeds, P.; Chuang, D.M. Valproic Acid and Other HDAC Inhibitors Upregulate FGF21 Gene Expression and Promote Process Elongation in Glia by Inhibiting HDAC2 and 3. Int. J. Neuropsychopharmacol. 2016, 19. [CrossRef]

50. Kuroda, M.; Muramatsu, R.; Maedera, N.; Koyama, Y.; Hamaguchi, M.; Fujimura, H.; Yoshida, M.; Konishi, M.; Itoh, N.; Mochizuki, H.; et al. Peripherally derived FGF21 promotes remyelination in the central nervous system. J. Clin. Investig. 2017, 127, 3496-3509. [CrossRef]

51. Iwata, T.; Hevner, R.F. Fibroblast growth factor signaling in development of the cerebral cortex. Dev. Growth Differ. 2009, 51, 299-323. [CrossRef] [PubMed]

52. Shahror, R.A.; Linares, G.R.; Wang, Y.; Hsueh, S.C.; Wu, C.C.; Chuang, D.M.; Chiang, Y.H.; Chen, K.Y. Transplantation of Mesenchymal Stem Cells Overexpressing Fibroblast Growth Factor 21 Facilitates Cognitive Recovery and Enhances Neurogenesis in a Mouse Model of Traumatic Brain Injury. J. Neurotrauma 2019. [CrossRef] [PubMed]

53. Miller, F.D.; Gauthier, A.S. Timing Is Everything: Making Neurons versus Glia in the Developing Cortex. Neuron 2007, 54, 357-369. [CrossRef] [PubMed]

54. Wei, Z.; Sun, M.; Liu, X.; Zhang, J.; Jin, Y. Rufy3, a protein specifically expressed in neurons, interacts with actin-bundling protein Fascin to control the growth of axons. J. Neurochem. 2014, 130, 678-692. [CrossRef] [PubMed]

55. Vernon, C.G.; Swanson, G.T. Neto2 Assembles with Kainate Receptors in DRG Neurons during Development and Modulates Neurite Outgrowth in Adult Sensory Neurons. J. Neurosci. Off. J. Soc. Neurosci. 2017, 37, 3352-3363. [CrossRef]

(C) 2020 by the authors. Licensee MDPI, Basel, Switzerland. This article is an open access article distributed under the terms and conditions of the Creative Commons Attribution (CC BY) license (http://creativecommons.org/licenses/by/4.0/). 